\title{
Possible Roles of Interleukin-4 and -13 and Their Receptors in Gastric and Colon Cancer
}

\author{
Xujun Song, Benno Traub $\mathbb{D}$, Jingwei Shi and Marko Kornmann * \\ Department of General and Visceral Surgery, Ulm University Hospital, Albert-Einstein-Allee 23, \\ 89081 Ulm, Germany; 101012268@seu.edu.cn (X.S.); benno.traub@uniklinik-ulm.de (B.T.); \\ shijingwei555@126.com (J.S.) \\ * Correspondence: marko.kornmann@uniklinik-ulm.de; Tel.: +49-731-500-53560
}

check for updates

Citation: Song, X.; Traub, B.; Shi, J.; Kornmann, M. Possible Roles of Interleukin-4 and -13 and Their Receptors in Gastric and Colon Cancer. Int. J. Mol. Sci. 2021, 22, 727. https://doi.org/10.3390/ijms 22020727

Received: 20 December 2020 Accepted: 8 January 2021 Published: 13 January 2021

Publisher's Note: MDPI stays neutral with regard to jurisdictional clai$\mathrm{ms}$ in published maps and institutional affiliations.

Copyright: (C) 2021 by the authors. Licensee MDPI, Basel, Switzerland. This article is an open access article distributed under the terms and conditions of the Creative Commons Attribution (CC BY) license (https:// creativecommons.org/licenses/by/ $4.0 /)$.

\begin{abstract}
Interleukin (IL)-4 and -13 are structurally and functionally related cytokines sharing common receptor subunits. They regulate immune responses and, moreover, are involved in the pathogenesis of a variety of human neoplasms. Three different receptors have been described for IL-4, but only IL-4 receptor type II (IL-4R $\alpha / \mathrm{IL}-13 \mathrm{R} \alpha 1$ ) is expressed in solid tumors. While IL-13 can also bind to three different receptors, IL-13 receptor type I (IL-4R $\alpha / \mathrm{IL}-13 \mathrm{R} \alpha 1 / \mathrm{IL}-13 \mathrm{R} \alpha 2)$ and type II (IL-4R $\alpha / \mathrm{IL}-13 \mathrm{R} \alpha 1$ ) are expressed in solid tumors. After receptor binding, IL-4 and IL-13 can mediate tumor cell proliferation, survival, and metastasis in gastric or colon cancer. This review summarizes the results about the role of IL-4/IL-13 and their receptors in gastric and colon cancer.
\end{abstract}

Keywords: interleukin-4; interleukin-13; interleukin-4 receptor; interleukin-13 receptor; gastrointestinal cancer

\section{Introduction}

Gastric cancer (GC) and colon and rectal cancer (CRC) are common malignancies of the digestive system [1,2]. Despite advances in earlier detection, multimodal treatment, and surgical management, the prognosis of both entities is still unsatisfactory [3]. CRC is the second leading cause of all tumor deaths in the United States [3], and stomach cancer is the third leading death cause of cancer-related deaths worldwide [4]. Alternative or additional treatment strategies especially for advanced tumor stages are desperately needed to overcome drug resistance, enhance chemosensitivity, inhibit tumor cell proliferation, and induce apoptosis in order to further improve outcome [1,2,5-9].

More and more evidence has been provided in recent years that interleukin-4 (IL-4), interleukin-13 (IL-13), and their receptors play an important role in cancer cell proliferation and other biological behaviors, such as migration and invasion enhancing the malignant phenotype [10-12]. Moreover, IL-4/IL-13 and their receptors have been also associated with apoptosis, chemosensitivity, and prognosis in various cancers [13-15]. IL-4 and IL-13 are also involved in the crosstalk with the tumor microenvironment (TME) by activating tumor-associated macrophages and myeloid-derived suppressor cells, which have tumor promoting functions [16,17]. Immune surveillance against established metastatic mammary cancer is negatively regulated by IL-13 in mice [18]. The aim of this review was to summarize the current information about the role of IL-4/IL-13 and their receptors in GC and CRC.

\section{Methods}

A literature search in PubMed was carried out in April 2020 using "interleukin-4" or "interleukin-13" or "interleukin-4 receptor" or "interleukin-13 receptor" in combination with "gastric cancer" or "colon cancer" or "colorectal cancer" or "rectal cancer", respectively. A total number of 452 articles were retrieved. Duplicate articles were eliminated, and 
additional articles were identified through references cited in retrieved articles. Only manuscripts and reviews in the English language were included in this review.

The articles about single nucleotide polymorphisms (SNPs) were searched in May 2020 using "interleukin-4" or "interleukin-13" or "interleukin-4 receptor" or "interleukin-13 receptor" and "polymorphism OR mutation OR variation" in combination with "colorectal cancer" or "colon cancer" or "rectal cancer". Sixty-four articles about SNPs of IL-4/IL-13 and their receptors in CRC were identified. A total of 67 articles about SNPs of IL-4/IL13 and their receptors in GC were retrieved using "interleukin-4" or "interleukin-13" or "interleukin-4 receptor" or "interleukin-13 receptor" and "polymorphism OR mutation OR variation" and "gastric cancer". Our review included a total of 64 articles about SNPs of IL-4/IL-13 and their receptors in GC or CRC.

\section{Summary of the IL-4/-13 Signaling Pathway}

IL-4, first described in 1981, is a secreted cytokine that, in its physiologic function, can regulate antibody production, hematopoiesis, and inflammation, and is also involved in the development of effector T-cell responses [19]. The closely related IL-13, first described in 1993, is a human lymphokine that can regulate inflammatory and immune responses [20]. IL-4 and IL-13 are essential for the induction and persistence of the type 2 immune response, and they are associated with multiple atopic diseases, such as asthma and atopic dermatitis [21]. IL-4 and IL-13 are mainly produced by immune cells, such as CD4-T-cells, basophils, eosinophils, and natural killer T (NKT) cells [22].

The structure of IL-4 receptor (IL-4R), IL-13 receptor (IL-13R), and the positions of the intracellular signaling molecules of them have been summarized in several articles [23-26]. There are three different kinds of IL-4 receptors (Figure 1). IL-4 binds to the IL-4R $\alpha$ chain, then recruits the IL-2R $\gamma$-common $(\gamma \mathrm{c})$ chain (type I IL-4R) or the IL-13R $\alpha 1$ chain (type II IL-4R) to form a receptor complex that can initiate signal transduction [25]. The type III IL-4R is formed by all the three chains [27]. IL-13 can also signal via three different receptors (Figure 1). The type II IL-13R complex has the same components as the type II IL-4R [28]. IL-13R type I (IL-4R $\alpha /$ IL-13R $\alpha 1 /$ IL-13R $\alpha 2)$ and type II (IL-4R $\alpha /$ IL-13R $\alpha 1$ ) are expressed in non-hematopoietic cells, while type III (IL-4R $\alpha /$ IL-13R $\alpha 1 / \gamma c)$ is only expressed on the surface of hemocytes [27]. Overall, this results in a possible complex web of IL-4- and IL-13-mediated signaling pathways [29].

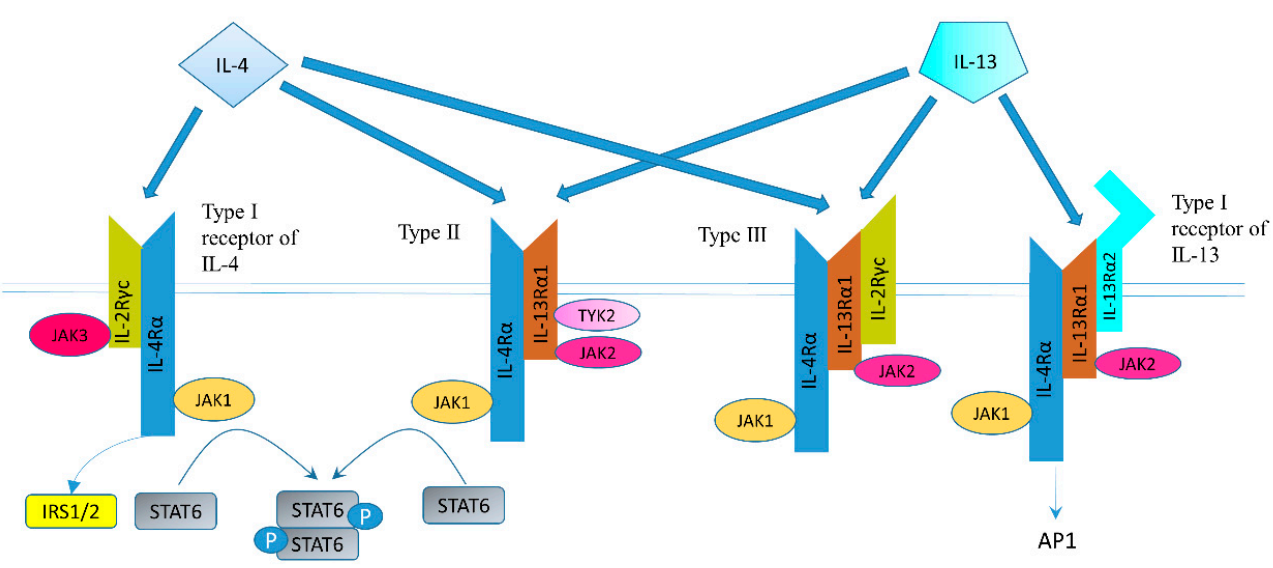

Figure 1. Receptor types and signal transduction of IL-4R and IL-13R. There are three different kinds of IL-4 receptors. IL-4 binds to the IL-4R $\alpha$ chain, then recruits the IL- $2 \mathrm{R} \gamma$-common $(\gamma \mathrm{c})$ chain (type I IL-4R) or the IL-13R $\alpha 1$ chain (type II IL-4R) to form a receptor complex that can initiate signal transduction. The type III IL-4R consists of all three chains. IL- 13 also have three different receptors. IL-13 receptor type I (IL-4R $\alpha /$ IL-13R $\alpha 1 /$ IL-13R $\alpha 2$ ) and type II (IL-4R $\alpha /$ IL-13R $\alpha 1)$ are expressed in solid tumors, while type III (IL-4R $\alpha /$ IL- $13 R \alpha 1 / \gamma \mathrm{c}$ ) is expressed in hemocytes only. IL-13 binds IL-13R $\alpha 1$ with a low affinity and complexes with the IL-4R $\alpha$ (type II receptor). IL-13 binds to the IL-13R $\alpha 2$ with a high affinity. IL-13 can bind to a soluble IL-13R $\alpha 2$ receptor, which has no downstream signaling, or bind to transmembrane IL-13R $\alpha 2$ and activate AP-1. Figure sketch adapted from reference [27]. 
With regard to the IL-13R $\alpha 2$ chain, IL-13 is not the sole ligand. For example, chitinase3-like protein 1 (CHI3L1) could bind to IL-13R $\alpha 2$ and regulate oxidant injury, apoptosis, and melanoma metastasis [30]. Transmembrane protein 219 and CD44 play an important role in IL-13R $\alpha 2$ mediated signaling which is induced by CHI3L1 [31,32].

Altogether, IL-4R and IL-13R share two receptor chains (IL-4R $\alpha$ and IL-13R $\alpha 1$ ) and can mediate common, but also diverse biological functions [27]. Both IL-4 and IL-13 phosphorylate and activate signal transducer and activator of transcription (STAT) 6 [27]. STAT3, STAT5, and STAT1 can also be activated, but to a lesser degree [23]. IL-4 can signal through IRS-2 (generally expressed by hematopoietic cells) or IRS-1 (generally nonhematopoietically expressed) [23]. As mentioned above, IL-13 could bind to the IL-13R $\alpha 2$ chain, which has a very high affinity for IL-13. The downstream signaling involves AP-1 family members c-jun and Fra-2 [33]. IL-13R $\alpha 2$ can inhibit downstream signals of IL-13R and IL-4R through regulating STAT6 [34,35].

\section{IL-13/IL-13R in Gastric Cancer}

IL-13Rs are overexpressed in several human solid cancer cell lines [36,37]. Our group demonstrated that IL-13R and IL-4R were expressed in pancreatic cancer cell lines, such as PANC-1, MIAPaCa-2, and CAPAN-1 [38]. Their proliferation was inhibited by Pseudomonas exotoxin (PE) combined to IL-13 or IL-4, demonstrating the receptor's functionality [38]. IL-13R $\alpha 2$ is expressed in HS766T and MIAPaCa-2 pancreatic cancer cells, as well [36]. One recombinant chimeric protein IL-13PE was found highly cytotoxic to GC cell line CRL1739, which also expressed the type II IL-4R receptor (Figure 1) binding both IL-4 and IL-13 [39]. IL-13R $\alpha 2$ is also expressed in GC cell lines MKN-45, AGS and MGC308 [32,40].

Gabitass et al. evaluated plasma IL-13 and IL-4 levels in 131 patients (46 pancreatic cancer, 25 GC, and 60 esophageal cancer) and 54 healthy controls [41]. IL-13 levels in patients' plasma were significantly higher in all the three cancer patients compared with controls [41]. In another study, Lin et al. evaluated IL-13R $\alpha 2$ expression in tissue microarrays of 507 GC patients [15]. They found the overexpression of the IL-13R $\alpha 2$ chain in cancer tissue was associated with poor prognosis after gastrectomy [15].

Chen and coworkers showed that CHI3L1 secreted by M2 macrophage could promote the metastasis of GC cell lines MKN-45 and AGS by binding to the IL-13R $\alpha 2$ chain [40]. The mechanism is mediated by activating the mitogen-activated protein kinase signaling pathway, which upregulates the matrix metalloproteinase genes [40]. Geng et al. found CD44v3 could bind to both CHI3L1 and IL-13R $\alpha 2$ in GC cell lines AGS and MGC308 [32]. In this study, CHI3L1 expression was positively related to GC invasion depth and lymph node status in 100 GC tissues from patients [32]. A summary of the results is shown in Supplemental Table S1.

\section{IL-4/IL-4R in Gastric Cancer}

Human GC cell lines such as CRL1739 express IL-4R [42]. IL-4 inhibited proliferation of HTB-135 GC cells by down-regulating G0-G1 cell cycle nuclear-regulating factors, including retinoblastoma gene product, c-myc, and cyclin D1 [43]. IL-4 could cause G1 phase arrest in the GC cell line CRL 1739 by binding to IL-4R $\alpha$ and $\gamma c$ (type I IL-4R) [42]. IL-4 could also inhibit the growth of GC cells and this effect was positively related with IL-4R expression level of the respective cell lines [44]. The expression was detected by flow cytometry using biotin-labeled IL-4. It remains unclear, however, what type of IL-4R causing inhibition of GC cell growth was expressed (Figure 1).

Gabitass et al. found plasma IL-4 levels in 25 GC patients were significantly higher than in 54 healthy controls [41]. Cárdenas et al. found serum IL-4 levels in 17 GC patients were significantly elevated comparing with 30 healthy individuals by sandwich ELISA [45]. In their study, elevated serum levels of IL-4 indicated a higher risk of mortality, but there is no statistical association [45]. Orea and co-workers studied a total of 30 biopsies of GC by immunohistochemistry [46]. They found a significantly higher expression of IL-4 in stages 
I and II than in stages III and IV, pointing to a possible growth inhibitory effect of IL-4 in GC [46]. A summary of the effects of IL-4 and IL-13 in GC is shown in Supplemental Table S1.

\section{IL-13/IL-13R in Colon and Rectal Cancer}

Expressions of IL-13/IL-13R in CRC: Immunoblot analysis demonstrated a high expression of IL-13R $\alpha 2$ in cultured metastatic colon cancer (CC) cell lines such as KM12SM, SW48, and HT29 [13]. Overexpression of IL-13R $\alpha 2$ was found in $66 \%$ of tumor samples from 80 CC patients [13]. In an immunohistochemical analysis of CRC patients at stage I-III, high IL-13 and IL-13R expression was seen in 50\% (181/359) and 42\% (152/359) of the cancers, respectively [47].

IL-13/IL-13R in CRC cell lines: IL-13 and IL-4 stimulated mucin 2 expression in CC cell line LS174T, but not in CC cell line HT-29 through the mitogen-activated protein kinase pathway [48]. IL-13 could inhibit the autophagic pathway in HT-29 cells via the activation of the class I phosphatidylinositol 3-kinase (PI3K) [49]. The tumor suppressor phosphatase and tensin homolog (PTEN) is expressed in HT-29 cells. Its overexpression directed by an inducible promoter counteracted the IL-13 down-regulation of macroautophagy, which is the most prevalent form of autophagy [50]. One recombinant chimeric protein IL-13PE was cytotoxic to CC cell lines Colo201 and Colo205 [39]. Another study revealed that IL-13 induced phosphorylation of Janus kinase (JAK) 2, JAK1, and Tyk2 in CC cell lines HT-29 and WiDr [51]. In addition, both IL-13 and IL-4 could induce phosphorylation of STAT6 [51]. In human colonic epithelial cell lines, IL-13 and IL-4 upregulated the expression of CD44 [52]. Bartolomé et al. demonstrated that family with sequence similarity 120A (FAM120A) in the IL-13/IL-13R $\alpha 2$ signaling pathway was an important mediator of invasion and liver metastasis using CC cell lines such as SW620, KM12C, and KM12SM, and nude mice that were inoculated with CC cells in the spleen [11]. KM12C and KM12SM human CC cells only differ in their metastatic properties [53]. Bartolomé et al. found that FAM120A could mediate the IL-13R $\alpha 2$-induced activation of the FAK and $\mathrm{PI} 3 \mathrm{~K} / \mathrm{AKT} / \mathrm{mTOR}$ pathways [11]. FAM120A could function as a scaffold protein for PI3K to be phosphorylated by Src family kinases [11]. Propofol suppressed cell proliferation and IL-13 induced epithelial-mesenchymal transition (EMT) in CRC cell lines RKO and SW480 [54]. It could be demonstrated that propofol suppressed IL-13/STAT6 signaling by upregulating STAT6 targeting miRNAs [54]. IL-13 promoted EMT and aggressiveness of HT-29 and SW480 cells through IL-13R $\alpha 1 /$ STAT6/ZEB1 pathway [55]. IL-13 was found to induce the expression of $11 \beta$-hydroxysteroid dehydrogenase type 2 (11ßHSD2) via IL-13R $\alpha 2$ in CRC cell line SW480 and murine CRC cell line CT26 [56].

IL-13/IL-13R in CRC mouse models: Glycyrrhizic acid, an inhibitor of 11ßHSD2, could reduce liver metastasis of CT26 cells in nude mice [56]. Protein tyrosine phosphatase-1B mediates IL-13-induced cancer cell proliferation, migration, and survival via Src activation [57]. IL-4 and IL-13 both up-regulated the expression of chemokine eotaxin-2 in CRC cell lines LS174T and LOVO [58]. However, this effect was not seen in CRC cell lines SW480 and COLO 205 [58]. More than a 10-fold increase of eotaxin-2 level was found in tissue-derived supernatants from colorectal hepatic metastases compared with normal liver in $23 / 25$ patients [58].

Matsui et al. studied the roles of inflammatory cytokines in obesity-related colorectal tumorigenesis [59]. Colorectal tumorigenesis was induced through intraperitoneal injection of azoxymethane in C57BL mice and obesity diabetes model mice KK and KK-Ay [59]. The group found that the formation of CRC was more frequent in obese mice than wild type mice [59]. Moreover, silencing IL-13R $\alpha 1$ with small interfering RNA inhibited IL-13induced proliferation in the CC cell line HT29 via downregulating STAT6 activation [59]. Another study found that the development of lung metastases could be significantly inhibited by an IL-13 inhibitor, but not by inhibition of IL-4 in a murine lung metastasis model of CC [60]. High expression of IL-13R $\alpha 2$ in the CC cell line KM12 was associated with invasion and liver metastasis in nude mice [13]. The mechanism might be the activation of the oncogenic signaling molecules such as PI3K and AKT by IL-13 [13]. High expression of 
IL-13R $\alpha 2$ was also associated with higher tumor stages and poor outcome in human CRC patients [13]. The IL-13R $\alpha 2$ D1 peptide inhibited proliferation, migration, and invasion in KM12SM and SW620 CC cells treated with IL-13 [61]. This peptide could block the signaling through IL-13R $\alpha 2$ and, at a lower level, IL-13R $\alpha 1$ [61]. Nude mice treated with the enantiomer D-D1 peptide had a significant longer survival time due to reduced development of liver metastasis [61].

IL-13/IL-13R in CRC patients: Ingram et al. studied the role of type II IL-4R in transgenic mouse models and human cases. They found reduced IL-4R increased CRC initiation but reduced tumor progression and did not show any effects on mortality [62]. In an immunohistochemical study including 359 CRC samples, patients who had high IL-13R expression had less lymph node metastases [47]. High IL-13 expression was associated with a longer survival time [47]. Saigusa et al. studied 241 patients with CRC and demonstrated that serum IL-13 levels were significantly lower in patients with advanced stage, and low IL-13 levels in the serum was significantly associated with poorer prognosis [63]. However, in a study measuring IL-13 protein levels in fecal samples, 20 CRC patients presented significantly higher IL-13 levels than 20 healthy controls [64].

A summary of the effects of IL-13/IL-13R in CRC cells are depicted in Supplemental Table S2 and the effects of IL-13/IL-13R in CRC mouse models or patients are depicted in Supplemental Table S3.

\section{IL-4/IL-4R in Colon Cancer}

Expressions of IL-4/IL-4R in colon cancer: Lahm et al. studied the expression of IL-4R in 7 CRC cell lines [65]. Fluorescent-activated cell sorting analysis showed that three cell lines (WiDr, LS1034, HT29,) had a relatively higher expression of IL-4R, while the other four cell lines (Co-115, LS513, SW1116, LS411N) had lower expression [65]. Higher expression levels of IL-4 and IL-13 were found in the serum or the tumor homogenates of a CT26 tumorbearing mouse model [66]. In an analysis of IL-4R expression in 44 CRC patients using immunohistochemistry, positive labelling was obtained in 40/44 carcinomas [67]. In an immunohistochemical study of CRC patients at stage I-III, high IL-4 and IL-4R expression were detected in 33\% (118/359) and 36\% (129/359) of the samples, respectively [47].

IL-4/IL-4R in colon cancer cell lines Liu and colleagues found IL-4 and IL-13 increased nicotinamide adenine dinucleotide phosphate oxidase 1-related proliferation in HT-29 and DLD-1 human CC cells [12]. In their experiments, IL-4 promoted HT-29 cell proliferation for a nearly 2-fold increase after four days of treatment [12]. Koller et al. found the addition of IL-4 resulted in proliferation of HT-29 and HCT 116 CC cells [68]. In contrast, Chang et al. demonstrated that IL-4 inhibited the proliferation of HT-29 and WiDr CC cells, while it promoted cell proliferation of Burkitt's lymphoma cell lines BL30 and BL41 [69]. Furthermore, Toi et al. found that IL-4 inhibited cell proliferation of HT-29 cells [70]. According to Topp et al. recombinant human IL- 4 had an antiproliferative effect on HTB 38 CC cells [71]. Additional studies also found discrepancies in the effect of IL-4 regarding cell growth $[65,72,73]$. Interestingly, when evaluating cell proliferation Lahm et al. found a significant inhibition of thymidine uptake in CC cell line LS411N by IL-4, but not by using MTT assay [65]. The different effects of IL-4 on cell proliferation in CC cell lines are summarized with regard to cell line, growth conditions and duration, ligand source and concentration, and type of proliferation assay in Table 1.

IL-4 was identified to promote EMT in CRC cell lines HCT 116 and RKO via STAT6 [74]. Koller et al. found that IL-4R $\alpha$-the subunit of type II IL-4R in epithelial cells (Figure 1)expression promoted tumor growth in human CC cell lines HCT116, HT-29, DLD-1, SW480, SW620, Caco2, and HCA7, while IL-4 could only decrease apoptosis in HCT116 cells [68]. IL-2, IL-12, and IFN-alpha enhanced antibody-dependent cellular cytotoxicity (ADCC) against HT-29 cells and IL-4 could significantly suppress this effect [75]. Wersäll et al. demonstrated that pretreatment with IL-4 enhanced the ADCC activity of peripheral blood mononuclear cells (PBMCs), monocytes, and natural killer cells against SW948 CRC cells [76]. Recombinant human IL-4 inhibited IL-2-dependent activation and proliferation 
of human NK cells [77]. Nieroda et al. found a significant enhancement in ADCC activity against human CC lines LS174T and CBS after peripheral monocytes were pretreated with human macrophage colony-stimulating factor [78]. IL-4 could further enhance the ADCC activity on LS174T CC cells when tested with the peripheral monocytes from two donors [78]. Flieger et al. found IL-4 could reduce the IL-2, IL-12, and IFN-alpha-induced ADCC by flowcytometric cytotoxicity assay [79]. They used PKH-2 labeled HT-29 cells as target cells and PKH-26 labeled human PBMCs as effector cells [79]. IL-4 sensitized SW620 cells to radiation through inhibition of NF- $\mathrm{kB}$ [80]. Flieger et al. demonstrated IL-4 can decrease both epithelial cellular adhesion molecule and LewisY expression in HT-29 and LoVo cells, but not in SW480 cells [81]. In LS174T CC cells, IL-4 induced down-regulation of stem cell factor and its receptor c-kit, and inhibited proliferation induced by the factor [82]. The addition of IL-4 increased IL-8 release in CRC cell line HT115, but not in CRC cell lines HRT18 and H29/6 [83].

IL-4 could inhibit cell-cell adhesion without affecting cell proliferation in human CC cell line Colo205 [84]. IL-4 and IL-13 inhibited CC cell-cell adhesion via downregulation of E-cadherin and carcinoembryonic antigen molecules [84]. IL-4 was an inhibitor of hepatocyte growth factor, which could regulate hepatocyte growth factor-induced cell proliferation and other events like cell migration and invasive ability in CC [85]. JAK1 and JAK2 were phosphorylated and activated after IL-4 addition in human CC cell lines HT-29 and WiDr [86]. IL-4 changed the expression of integrin and decreased the lung-colonizing ability of HT-29 CC cells [87].

IL-4 and cancer stem cells in CC: Todaro et al. found that CC growth was determined by stem-like cells, which were characterized by the expression of CD133 and were resistant to chemotherapy due to the autocrine of IL-4 [14]. Anti-IL-4 antibodies inhibited the tumor growth in human CC cell line Caco [88]. Moreover, neutralizing of IL-4 increased the efficacy of chemotherapy and inhibited the CD133+ cell population by increasing their tendency to undergo apoptosis. [88].

Li et al. identified different IL-4/Stat6 activities in CRC cell lines using electrophoretic mobility shift assay [89]. They found HT-29 was an active Stat6 high phenotype and Caco-2 a defective Stat6 null phenotype [89]. HT-29 cells were resistant to apoptosis and showed more aggressive metastasis compared with Caco-2 cells [89]. The mechanism involved genes associated with apoptosis or metastasis, such as survivin and p53 [89].

IL-4/IL-4R in CRC mouse models: Addition of IL-4 improved muscle function and lifespan of CC-bearing mice [90]. Over-expression of IL-12 could inhibit IL-4 and STAT6 in human CC stem cells and inhibit the survival of CC stem cells in vitro and their tumor formation ability in mice [91]. IL-4 combined with CpG oligonucleotide activated tumor-specific Th1-type immune responses and suppressed the tumor growth in a subcutaneous tumor model of C57BL/6 (B6) mice [92]. An IL-4R $\alpha$ aptamer-liposome-CpG oligodeoxynucleotide delivery system was demonstrated to enhance anti-tumor activity in CT26 tumor-bearing mice [93]. This system could deliver CpG into tumors and overcome TME immunosuppression [93]. Expression of IL-4 in the mouse CC cell line colon 26 inhibited tumor growth by inducing local tumor killing and systemic immunity in mice [94]. IL-4 gene transduced MC38 murine CRC cell line promoted a Th1-type response and tumor-specific immune responses in B6 mice [95].

IL-4/IL-4R in CRC patients: Six independent studies evaluated IL-4 serum levels in CRC patients. Five studies showed significantly higher levels of IL-4 in patients compared to healthy controls [96-100]. Additionally, Berghella et al. found IL-4 levels in the serum to be predictive for cancer staging and invasiveness [98]. Serum levels of IL- $4 \geq 431 \mathrm{pg} / \mathrm{mL}$ and IL-7 $\geq 54 \mathrm{pg} / \mathrm{mL}$ were associated with a $95 \%$ possibility of stage IV cancer [98]. Moreover, Zaloudik et al. provided evidence for a negative impact of increased IL-4 serum levels on CD8+ cytotoxic T-cells [99]. However, Kim et al. could not detect any IL-4 expression in serum, normal mucosa, or tumor tissue in 20 CRC patients with fluorescent bead-based detection assay [101]. 
Table 1. Effect of IL-4 on human colon cancer cell proliferation.

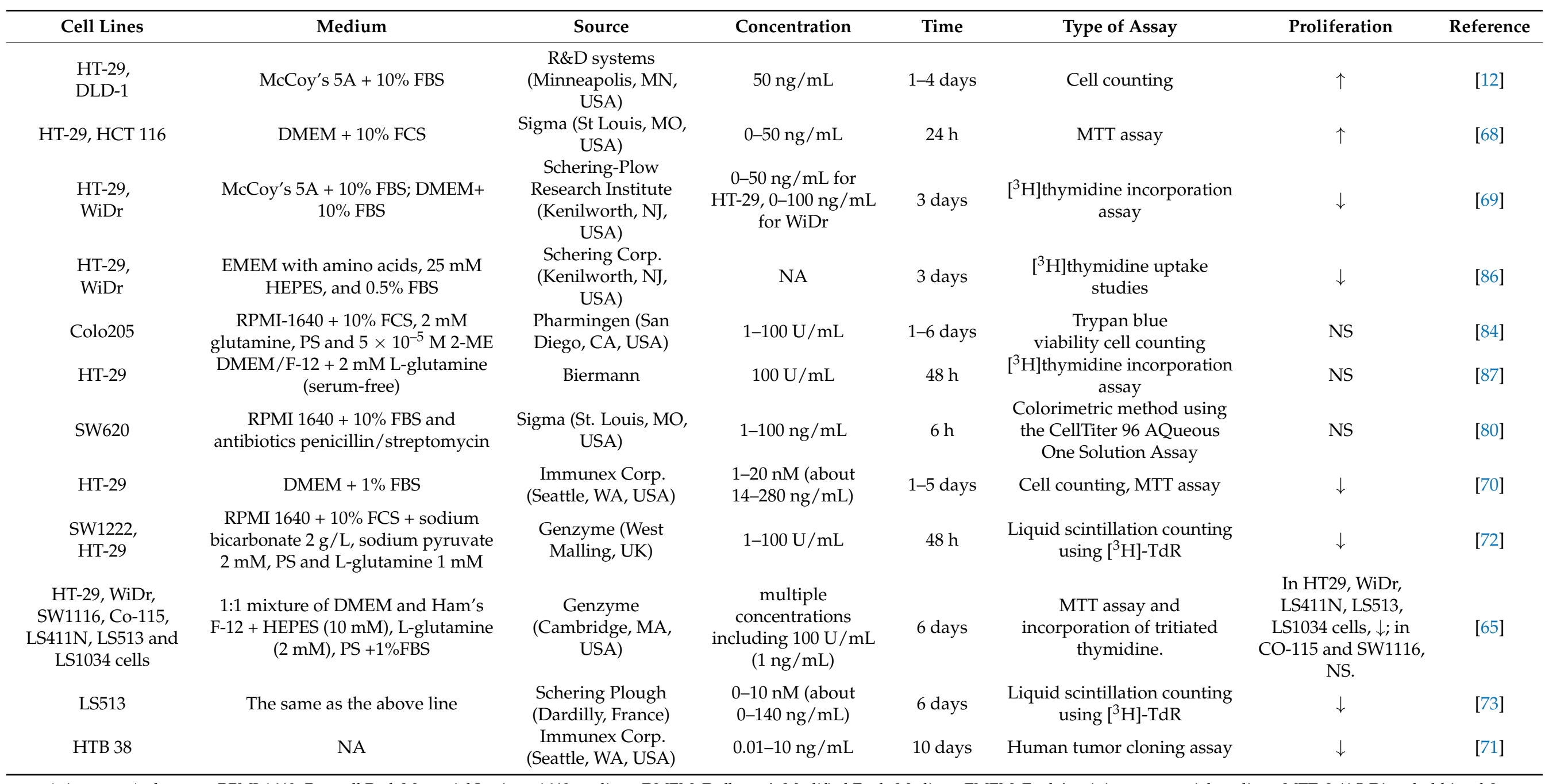

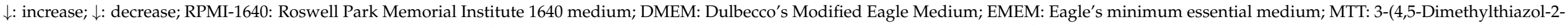

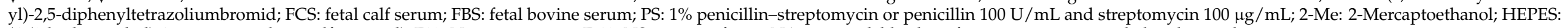
(4-(2-hydroxyethyl)-1-piperazineethanesulfonic acid); F12: Nutrient mixture F-12; NS: not significant; NA: not available, the information is not provided in the article. 
In an immunohistochemical study including 359 CRC samples, patients who had high expression of IL-4 and IL-4R showed less lymph node metastases [47]. Mechanistically, IL-4 was shown to increase the expression of survivin (an apoptosis inhibitor) by activating STAT6 in primary CC cells derived from surgical specimens [102]. Tumor-cell-derived IL-4 also mediated apoptosis resistance in primary human CC cells and the human CC cell line T84 [103]. IL-4 autocrine increased growth and survival of primary human CC cells [103].

Following the cancer-stem-cell model, Kim et al. isolated CD133(+) and CD133(-) cancer cells from four CRC patients by MagSweeper and did whole-transcriptome analysis [104]. In their study, the expression of IL-4 gene was significantly higher in CD133(+) cells than in CD133(-) CRC cells [104]. Furthermore, cancer-initiating cells isolated from CRC patients showed weak immunogenicity in vitro because of their membrane-bound IL-4 [105]. However, IL-4 originated from tumor infiltrating lymphocytes was associated with better prognosis [106]. This was immunohistochemically assessed in 49 primary CC and 20 metastases [106].

Correale et al. studied 41 metastatic CRC patients and found that patients with higher serum IL-4 levels had a longer overall survival when they receive the anticancer vaccine of thymidylate synthase poly-epitope-peptide [107]. Evans et al. recruited 80 CRC patients prior to treatment and 38 matched controls [108]. No significant difference was found between IL-4 production in patients and controls, which were measured from the supernatants of activated PBMCs [108]. In CRC patients, long-term n-3 and n- 6 essential fatty acids ingestion reduced total serum IL-4 by $69 \%(p=0.025)$ after six months [109]. Three months after stop taking essential fatty acids, cytokine levels returned to pre-supplementation values [109].

Besides Table 1, which describes effects of IL-4 on cell proliferation, Supplemental Tables S2 and S3 summarize all the findings about the effects of IL-4 and IL-13 in CRC.

\section{SNPs in IL-4/13 and Their Receptors in Gastric and Colon Cancer}

By definition, a short nucleotide polymorphism has a minor allele frequency of more than $1 \%$ in at least one population [110]. SNPs play an important role in mendelian diseases and studies focused on their role on more complex disease like cancer in recent years [111]. In a matched case-control study, patients with aerodigestive tract cancers were investigated for frequency of the G2463A polymorphism of the myeloperoxidase gene [112]. The 2463G/A transition strongly reduced mRNA expression of myeloperoxidase and reduced cancer risk [112]. The mechanism is that the polymorphic site is located in an Alu element and leads to the loss of a transcription factor binding site [113]. A SNP in the KRAS $3^{\prime}$ untranslated region that binds to let-7 microRNA increased the risk of non-small cell lung cancer [114]. Genetic association studies about SNPs in cancers can be divided into two categories, susceptibility study and outcome study. [115].

There are a lot of articles about SNPs of IL-4/IL-13 or their receptors and association with gastric (summary in Supplemental Table S4 [45,116-142]) or colorectal (summary in Supplemental Table S5 [62,137,143-162]) cancer. Some of them revealed certain kinds of SNPs may serve as a risk factor or prognostic marker for each disease [150]. For example, in Swedish CRC patients, Shamoun et al. found IL-13 SNP rs1800925 is a risk factor while IL-4 SNP rs2243250 may serve as a prognostic marker especially in stage III CRC [150]. Some authors did not find any significant associations between SNPs of IL-4/IL-13 or their receptors and GC or CRC $[163,164]$. In addition, the results of available meta-analysis and previous systemic analysis were separately summarized in Table 2 [163-174].

Many reports about SNPs in gastric and CC that have been published were summarized in Table 2, Tables S4 and S5. However so far, no SNP of IL-4/IL-13 or their receptors managed to enter clinical routine diagnostics or even influence treatment of gastric or colorectal cancer. Perhaps further studies are needed in order to be relevant for clinical applications. 
Table 2. Meta-analysis or combined studies about polymorphisms of IL-4/IL-13 and their receptors in gastric cancer (GC) and colon and rectal cancer (CRC).

\begin{tabular}{|c|c|c|c|}
\hline First Author (Year) & Number of Studies/Articles & SNPs & Result \\
\hline Zongjing Xie (2019) [163] & 18 & polymorphisms in IL-4 & $\begin{array}{l}\text { No significant association was found between } \\
\text { polymorphisms in IL-4 and GC in combined analyses. }\end{array}$ \\
\hline Jie Zhang (2013) [164] & 8 studies about GC, 3 studies about CRC & IL-4 -590C > T (rs2243250) & No significant association was found in GC and CRC. \\
\hline Young Ae Cho (2017) [165] & 27 & $\begin{array}{l}\text { IL-4: rs2243250, rs2070874; IL-13: rs1800925, } \\
\text { rs20541; IL-4R: rs1805010, rs1801275. }\end{array}$ & $\begin{array}{c}\text { The IL-4 rs } 2070874 \mathrm{~T} \text { allele was associated with an } \\
\text { increased risk of gastrointestinal cancer. The IL- } 4 \mathrm{R} \\
\text { rs1801275 heterozygote was associated with a reduced } \\
\text { risk of gastrointestinal cancer. }\end{array}$ \\
\hline Sun Z (2014) [166] & 7 & IL-4 -590C > T (rs2243250) & $\begin{array}{c}\text { IL-4 -590C > T polymorphism was associated with a } \\
\text { lower GC risk under dominant model and allelic mode } \\
\text { in Caucasians. }\end{array}$ \\
\hline Tie Wang (2016) [167] & 9 & IL-4 -590C > T (rs2243250) & $\begin{array}{c}\text { IL-4 }-590 \mathrm{C}>\mathrm{T} \text { polymorphism was not associated with } \\
\text { the susceptibility of GC. }\end{array}$ \\
\hline Zhang C (2016) [168] & 11 & IL-4 -590C > T (rs2243250) & $\begin{array}{l}\text { IL-4 rs2243250 polymorphism was not associated with } \\
\text { GC susceptibility. }\end{array}$ \\
\hline Jia Y (2017) [169] & $\begin{array}{l}7 \text { studies about GC, } 4 \text { studies about CRC for } \\
\text { rs2243250; } 2 \text { studies about GC for rs2070874; } 2 \\
\text { studies about GC for rs79071878. }\end{array}$ & IL-4: rs2243250, rs2070874, rs79071878 & $\begin{array}{l}\text { rs2243250 polymorphism was found to be associated } \\
\text { with an increased risk of GC. }\end{array}$ \\
\hline Liu Y (2018) [170] & $\begin{array}{c}3 \text { studies about GC for rs2227284; } 2 \text { studies } \\
\text { about GC for rs2243248; } 16 \text { studies about GC } \\
\text { for rs } 2243250 \text {; }\end{array}$ & $\begin{array}{l}\text { IL-4 -33T>C (rs2227284); IL-4 -1098T>G } \\
\text { (rs2243248); IL-4 -590C > T (rs2243250) }\end{array}$ & $\begin{array}{l}\text { IL-4 rs2243250 polymorphisms was associated with } \\
\text { elevated GC risk in Asians. }\end{array}$ \\
\hline Loh M (2009) [171] & 203 & $\begin{array}{c}225 \text { polymorphisms across } 95 \text { genes, including } \\
\text { IL-4 -590C }>\text { T }\end{array}$ & $\begin{array}{c}\text { IL-4 -590C }>\text { T displayed conflicting effects between } \\
\text { Asian and Caucasian populations in GC. }\end{array}$ \\
\hline Mitsushige Sugimoto (2010) [172] & 5 & IL-4 -590C > T & $\begin{array}{c}\text { The risk of gastric non-cardia cancer development was } \\
\text { significantly associated with IL-4-590 T allele } \\
\text { carrier status. }\end{array}$ \\
\hline Huanlei Wu (2014) [173] & 5 & IL-4 $-524 \mathrm{C}>\mathrm{T}$ & $\begin{array}{c}\text { IL-4 -524C }>\text { T polymorphism was not associated with } \\
\text { an increased CRC susceptibility. }\end{array}$ \\
\hline
\end{tabular}

GC: gastric cancer; CRC: colon and rectal cancer; SNPs: single nucleotide polymorphisms. 


\section{Discussion and Outlook}

Multiple studies have focused on the effects of IL-4 and -13 in several epithelial cancers $[175,176]$. In CC, most of the results showed anti-proliferative effects. However, as summarized in Table 1, the effect of IL-4 on proliferation in CC cells is varying and may depend on multiple factors, among them cell line intrinsic differences. These results also point out that IL-4/IL-13 and their receptors can activate different signaling pathways and thus may have different biological functions in different types of human cancer cells. This knowledge is important when using neutralizing or blocking antibodies. Ito et al. found that addition of an IL-4 neutralizing antibody enhanced anti-tumor immunity and inhibited tumor growth in a mouse subcutaneous tumor model of murine CC cell line CT26 [177]. However, one has to keep in mind that systemic modulation of IL-4 as well as IL-13 signaling can also cause severe side-effects like a propensity towards helminth infections or acute gastric mucosal injury $[178,179]$.

Chimeric proteins composed of IL-13 or IL-4 with PE were invented to target human cancer cells expressing the corresponding receptors $[39,180]$. These chimeric proteins were found effective on different kinds of cancer cell lines, such as pancreatic cancer, CC, and GC cell lines [180-182]. Human glioma cells were extremely sensitive, too [183].

A Phase 2 study was conducted on patients who had recurrent glioblastoma multiforme (GBM) [184]. The patients received circularly permuted IL-4PE first, and then surgical resection [184]. A Phase 3 clinical trial was carried out to compare intraparenchymal IL-13PE administration with an FDA-approved drug called Gliadel wafers for recurrent GBM [185]. It was found that the time-to-progression was significantly longer with IL-13PE compared to Gliadel wafers [185].

A hybrid peptide named IL-4R $\alpha$-lytic peptide could bind to IL- $4 R \alpha$ on pancreatic cancer cells and the lytic peptide could kill the cancer cells in vitro and in vivo [186]. IL-4Rtargeted liposomal doxorubicin could be used to deliver drug to the human GBM 8401 cells in a mouse model [187]. Recombinant adenovirus, which expressed IL-13 on its surface, transferred genes to IL-13R $\alpha$ 2-expressing malignant glioma cells more effectively [188]. An IL-13R $\alpha 2$ antibody could bind to glioma cells, inhibit tumor growth, and improve the survival time in a glioma xenograft mouse model [189]. IL-13R $\alpha 2$-targeted cancer vaccines also showed effects in malignant gliomas in children, such as peptide-based cancer vaccine [190-192]. However, no articles about a similar vaccine were found for patients with GC or CC.

Chimeric antigen receptor T cells expressing IL-13 can kill target cells and have been studied in GBMs. For treating human glioma xenografts in rats, single intracranial injections of IL-13 “designer T cell” into tumor sites significantly increased survival [193]. However, as the researchers demonstrated, systemic administration of IL-13 "designer $\mathrm{T}$ cell" might be complicated by reaction against normal tissues which also express IL$13 R \alpha 1$ [193]. Using a mouse model in which tumors show a growth-regression-recurrence pattern, Terabe et al. demonstrated NKT cells and IL-13, which signals through the IL-4RSTAT6 pathway, played an important role in escaping tumor immunosurveillance [194]. By using an IL-13 inhibitor (sIL-13R $\alpha 2-\mathrm{Fc}$ ), they found that IL-13 is essential for the tumor recurrence, while IL-4 is not [194].

Extracellular matrix and stromal cells constitute the main structure of the TME [195]. Different types of immune and non-immune cells are found in TME and with various cytokines they secrete, these drive a chronic inflammatory and immunosuppressive intratumoral environment [196]. Among the immune cells in the TME, macrophages are very abundant and can be found at all tumor stages, generally playing a pro-tumoral role [197]. Th2 (T helper type 2 ) cells could block $\mathrm{T}$ cell-induced tumor rejection by producing Th2 cytokines including IL-4 and IL-13, which can induce the formation of immunosuppressive type 2-polarized macrophages [198]. Reducing M2-type macrophages, increasing M1-type macrophages and switching M2 macrophages into M1 phenotype in tumors could inhibit tumor growth and metastases $[199,200]$. 
Future studies could focus on the down-stream signaling of IL-4R and IL-13R in different tumors. Since treatment of GBM using IL-4 and IL-13 immunotoxins is advanced compared to other tumors, more efforts should be taken to test these treatment options also in advanced gastrointestinal cancers.

\section{Conclusions}

IL-4 and IL-13 as well as their receptors are expressed in and play important roles for the progression of several different kinds of cancers. Results with regard to biological functions may vary among different cell lines or even the same cell line and tumor types, so cytokine treatment would have to be individually designed for each patient. Clinical trials have already proven that IL-4 and IL-13 immunotoxins are effective for GBM treatment. One possibility to include these agents soon into clinical treatment may be regional intraarterial treatment of liver metastases showing high receptor expression. With further research, it is maybe also possible to include new treatment strategies targeting the IL-4/13 signaling system in more patients including primary and metastasized GC and CC.

Supplementary Materials: The following are available online at https: / www.mdpi.com/1422-0 067/22/2/727/s1, Table S1: Effects of IL-4/IL-13 in GC, Table S2: Effects of IL-4/IL-13 in CRC cells, Table S3: Effects of IL-4/IL-13 in CRC mouse models or patients, Table S4: Polymorphisms of IL-4/IL-13 and their receptors in GC, Table S5: Polymorphisms of IL-4/IL-13 and their receptors in CRC.

Author Contributions: X.S. completed the collection and analysis of relevant literature and wrote the first draft of the paper; B.T. and J.S. participated in the analysis of literature and the writing of the paper; M.K. conceived this review and guided the writing and revision of the article. All authors have read and agreed to the published version of the manuscript.

Funding: X.S. was funded by the 2019 Sino-German (China Scholarship Council-German Academic Exchange Service, CSC-DAAD) Postdoc Scholarship Program.

Institutional Review Board Statement: Not applicable.

Informed Consent Statement: Not applicable.

Data Availability Statement: Not applicable.

Acknowledgments: X.S. is also a surgeon in the department of general surgery, Zhongda Hospital, Medical School of Southeast University, Nanjing, Jiangsu, China. Currently he works as a postdoctoral researcher in Ulm, Germany.

Conflicts of Interest: The authors declare no conflict of interest.

$\begin{array}{ll}\text { Abbreviations } \\ \text { GC } & \text { Gastric cancer } \\ \text { CRC } & \text { Colon and rectal cancer } \\ \text { IL-4 } & \text { Interleukin-4 } \\ \text { IL-13 } & \text { Interleukin-13 } \\ \text { SNPs } & \text { Single nucleotide polymorphisms } \\ \text { NKT } & \text { Natural killer T } \\ \text { IL-4R } & \text { Interleukin-4 receptors } \\ \text { IL-13R } & \text { Interleukin-13 receptors } \\ \text { TC } & \text { IL-2R } \gamma \text {-common chain } \\ \text { CHI3L1 } & \text { Chitinase-3-like protein 1 } \\ \text { STAT } & \text { Signal transducer and activator of transcription } \\ \text { CC } & \text { colon cancer } \\ \text { PI3K } & \text { Phosphatidylinositol 3-kinase } \\ \text { PTEN } & \text { phosphatase and tensin homolog } \\ \text { JAK } & \text { Janus kinase } \\ \text { FAM120A } & \text { Family with sequence similarity 120A } \\ \text { EMT } & \text { Epithelial-mesenchymal transition }\end{array}$




$\begin{array}{ll}\text { 11ßHSD2 } & \text { 11ß-hydroxysteroid dehydrogenase type 2 } \\ \text { ADCC } & \text { Antibody-dependent cellular cytotoxicity } \\ \text { PBMCs } & \text { Peripheral blood mononuclear cells } \\ \text { GBM } & \text { Glioblastoma multiforme } \\ \text { PE } & \text { Pseudomonas exotoxin } \\ \text { TME } & \text { Tumor microenvironment } \\ \text { Th2 } & \text { T helper type } 2\end{array}$

\section{References}

1. Ilson, D.H. Advances in the treatment of gastric cancer. Curr. Opin. Gastroenterol. 2018, 34, 465-468. [CrossRef] [PubMed]

2. Dekker, E.; Tanis, P.J.; Vleugels, J.L.A.; Kasi, P.M.; Wallace, M.B. Colorectal cancer. Lancet 2019, 394, 1467-1480. [CrossRef]

3. Siegel, R.L.; Miller, K.D.; Jemal, A. Cancer statistics, 2020. CA Cancer J. Clin. 2020, 70, 7-30. [CrossRef] [PubMed]

4. Bray, F.; Ferlay, J.; Soerjomataram, I.; Siegel, R.L.; Torre, L.A.; Jemal, A. Global cancer statistics 2018: GLOBOCAN estimates of incidence and mortality worldwide for 36 cancers in 185 countries. CA Cancer J. Clin. 2018, 68, 394-424. [CrossRef] [PubMed]

5. Selim, J.H.; Shaheen, S.; Sheu, W.C.; Hsueh, C.T. Targeted and novel therapy in advanced gastric cancer. Exp. Hematol. Oncol. 2019, 8, 25. [CrossRef]

6. Patel, T.H.; Cecchini, M. Targeted Therapies in Advanced Gastric Cancer. Curr. Treat. Options Oncol. 2020, 21, 70. [CrossRef]

7. Tolba, M.F. Revolutionizing the landscape of colorectal cancer treatment: The potential role of immune checkpoint inhibitors. Int. J. Cancer 2020, 147, 2996-3006. [CrossRef]

8. Vincent, A.; Ouelkdite-Oumouchal, A.; Souidi, M.; Leclerc, J.; Neve, B.; Van Seuningen, I. Colon cancer stemness as a reversible epigenetic state: Implications for anticancer therapies. World J. Stem Cells 2019, 11, 920-936. [CrossRef]

9. Bess, S.N.; Greening, G.J.; Muldoon, T.J. Efficacy and clinical monitoring strategies for immune checkpoInt. inhibitors and targeted cytokine immunotherapy for locally advanced and metastatic colorectal cancer. Cytokine Growth Factor Rev. 2019, 49, 1-9. [CrossRef]

10. Traub, B.; Sun, L.; Ma, Y.; Xu, P.; Lemke, J.; Paschke, S.; Henne-Bruns, D.; Knippschild, U.; Kornmann, M. Endogenously Expressed IL-4Ralpha Promotes the Malignant Phenotype of Human Pancreatic Cancer In Vitro and In Vivo. Int. J. Mol. Sci. 2017, 18, 716. [CrossRef]

11. Bartolome, R.A.; Garcia-Palmero, I.; Torres, S.; Lopez-Lucendo, M.; Balyasnikova, I.V.; Casal, J.I. IL13 Receptor alpha2 Signaling Requires a Scaffold Protein, FAM120A, to Activate the FAK and PI3K Pathways in Colon Cancer Metastasis. Cancer Res. 2015, 75, 2434-2444. [CrossRef] [PubMed]

12. Liu, H.; Antony, S.; Roy, K.; Juhasz, A.; Wu, Y.; Lu, J.; Meitzler, J.L.; Jiang, G.; Polley, E.; Doroshow, J.H. Interleukin-4 and interleukin-13 increase NADPH oxidase 1-related proliferation of human colon cancer cells. Oncotarget 2017, 8, 38113-38135. [CrossRef] [PubMed]

13. Barderas, R.; Bartolome, R.A.; Fernandez-Acenero, M.J.; Torres, S.; Casal, J.I. High expression of IL-13 receptor alpha2 in colorectal cancer is associated with invasion, liver metastasis, and poor prognosis. Cancer Res. 2012, 72, 2780-2790. [CrossRef] [PubMed]

14. Todaro, M.; Alea, M.P.; Di Stefano, A.B.; Cammareri, P.; Vermeulen, L.; Iovino, F.; Tripodo, C.; Russo, A.; Gulotta, G.; Medema, J.P.; et al. Colon cancer stem cells dictate tumor growth and resist cell death by production of interleukin-4. Cell Stem Cell 2007, 1, 389-402. [CrossRef] [PubMed]

15. Lin, C.; Liu, H.; Zhang, H.; He, H.; Li, H.; Shen, Z.; Qin, J.; Qin, X.; Xu, J.; Sun, Y. Interleukin-13 receptor alpha2 is associated with poor prognosis in patients with gastric cancer after gastrectomy. Oncotarget 2016, 7, 49281-49288. [CrossRef]

16. Ostrand-Rosenberg, S. Immune surveillance: A balance between protumor and antitumor immunity. Curr. Opin. Genet. Dev. 2008, 18, 11-18. [CrossRef]

17. Wang, H.W.; Joyce, J.A. Alternative activation of tumor-associated macrophages by IL-4: Priming for protumoral functions. Cell Cycle 2010, 9, 4824-4835. [CrossRef]

18. Sinha, P.; Clements, V.K.; Ostrand-Rosenberg, S. Interleukin-13-regulated M2 macrophages in combination with myeloid suppressor cells block immune surveillance against metastasis. Cancer Res. 2005, 65, 11743-11751. [CrossRef]

19. Brown, M.A.; Hural, J. Functions of IL-4 and Control of Its Expression. Crit. Rev. Immunol. 2017, 37, 181-212. [CrossRef]

20. Minty, A.; Chalon, P.; Derocq, J.M.; Dumont, X.; Guillemot, J.C.; Kaghad, M.; Labit, C.; Leplatois, P.; Liauzun, P.; Miloux, B.; et al. Interleukin-13 is a new human lymphokine regulating inflammatory and immune responses. Nature 1993, 362, 248-250. [CrossRef]

21. Gandhi, N.A.; Pirozzi, G.; Graham, N.M.H. Commonality of the IL-4/IL-13 pathway in atopic diseases. Expert Rev. Clin. Immunol. 2017, 13, 425-437. [CrossRef] [PubMed]

22. Junttila, I.S. Tuning the Cytokine Responses: An Update on Interleukin (IL)-4 and IL-13 Receptor Complexes. Front. Immunol. 2018, 9, 888. [CrossRef] [PubMed]

23. Luzina, I.G.; Keegan, A.D.; Heller, N.M.; Rook, G.A.; Shea-Donohue, T.; Atamas, S.P. Regulation of inflammation by interleukin-4: A review of "alternatives". J. Leukoc. Biol. 2012, 92, 753-764. [CrossRef] [PubMed]

24. Oh, C.K.; Geba, G.P.; Molfino, N. Investigational therapeutics targeting the IL-4/IL-13/STAT-6 pathway for the treatment of asthma. Eur. Respir. Rev. 2010, 19, 46-54. [CrossRef] [PubMed] 
25. LaPorte, S.L.; Juo, Z.S.; Vaclavikova, J.; Colf, L.A.; Qi, X.; Heller, N.M.; Keegan, A.D.; Garcia, K.C. Molecular and structural basis of cytokine receptor pleiotropy in the interleukin-4/13 system. Cell 2008, 132, 259-272. [CrossRef] [PubMed]

26. Ul-Haq, Z.; Naz, S.; Mesaik, M.A. Interleukin-4 receptor signaling and its binding mechanism: A therapeutic insight from inhibitors tool box. Cytokine Growth Factor Rev. 2016, 32, 3-15. [CrossRef] [PubMed]

27. Suzuki, A.; Leland, P.; Joshi, B.H.; Puri, R.K. Targeting of IL-4 and IL-13 receptors for cancer therapy. Cytokine 2015, 75, 79-88. [CrossRef]

28. Aman, M.J.; Tayebi, N.; Obiri, N.I.; Puri, R.K.; Modi, W.S.; Leonard, W.J. cDNA cloning and characterization of the human interleukin 13 receptor alpha chain. J. Biol. Chem. 1996, 271, 29265-29270. [CrossRef]

29. Wills-Karp, M.; Finkelman, F.D. Untangling the complex web of IL-4- and IL-13-mediated signaling pathways. Sci. Signal. 2008, 1, pe55. [CrossRef]

30. He, C.H.; Lee, C.G.; Dela Cruz, C.S.; Lee, C.M.; Zhou, Y.; Ahangari, F.; Ma, B.; Herzog, E.L.; Rosenberg, S.A.; Li, Y.; et al. Chitinase 3-like 1 regulates cellular and tissue responses via IL-13 receptor alpha2. Cell Rep. 2013, 4, 830-841. [CrossRef]

31. Lee, C.M.; He, C.H.; Nour, A.M.; Zhou, Y.; Ma, B.; Park, J.W.; Kim, K.H.; Dela Cruz, C.; Sharma, L.; Nasr, M.L.; et al. IL-13Ralpha2 uses TMEM219 in chitinase 3-like-1-induced signalling and effector responses. Nat. Commun. 2016, 7, 12752. [CrossRef] [PubMed]

32. Geng, B.; Pan, J.; Zhao, T.; Ji, J.; Zhang, C.; Che, Y.; Yang, J.; Shi, H.; Li, J.; Zhou, H.; et al. Chitinase 3-like 1-CD44 interaction promotes metastasis and epithelial-to-mesenchymal transition through beta-catenin/Erk/Akt signaling in gastric cancer. J. Exp. Clin. Cancer Res. 2018, 37, 208. [CrossRef] [PubMed]

33. Fichtner-Feigl, S.; Strober, W.; Kawakami, K.; Puri, R.K.; Kitani, A. IL-13 signaling through the IL-13alpha2 receptor is involved in induction of TGF-beta1 production and fibrosis. Nat. Med. 2006, 12, 99-106. [CrossRef] [PubMed]

34. Wood, N.; Whitters, M.J.; Jacobson, B.A.; Witek, J.; Sypek, J.P.; Kasaian, M.; Eppihimer, M.J.; Unger, M.; Tanaka, T.; Goldman, S.J.; et al. Enhanced interleukin (IL)-13 responses in mice lacking IL-13 receptor alpha 2. J. Exp. Med. 2003, 197, 703-709. [CrossRef]

35. Rahaman, S.O.; Sharma, P.; Harbor, P.C.; Aman, M.J.; Vogelbaum, M.A.; Haque, S.J. IL-13R(alpha)2, a decoy receptor for IL-13 acts as an inhibitor of IL-4-dependent signal transduction in glioblastoma cells. Cancer Res. 2002, 62, 1103-1109.

36. Fujisawa, T.; Joshi, B.; Nakajima, A.; Puri, R.K. A novel role of interleukin-13 receptor alpha2 in pancreatic cancer invasion and metastasis. Cancer Res. 2009, 69, 8678-8685. [CrossRef]

37. Murata, T.; Obiri, N.I.; Debinski, W.; Puri, R.K. Structure of IL-13 receptor: Analysis of subunit composition in cancer and immune cells. BioChem. Biophys Res. Commun. 1997, 238, 90-94. [CrossRef]

38. Kornmann, M.; Kleeff, J.; Debinski, W.; Korc, M. Pancreatic cancer cells express interleukin-13 and -4 receptors, and their growth is inhibited by Pseudomonas exotoxin coupled to interleukin-13 and -4. Anticancer Res. 1999, 19, 125-131.

39. Debinski, W.; Obiri, N.I.; Pastan, I.; Puri, R.K. A novel chimeric protein composed of interleukin 13 and Pseudomonas exotoxin is highly cytotoxic to human carcinoma cells expressing receptors for interleukin 13 and interleukin 4. J. Biol. Chem. 1995, 270, 16775-16780. [CrossRef]

40. Chen, Y.; Zhang, S.; Wang, Q.; Zhang, X. Tumor-recruited M2 macrophages promote gastric and breast cancer metastasis via M2 macrophage-secreted CHI3L1 protein. J. Hematol. Oncol. 2017, 10, 36. [CrossRef]

41. Gabitass, R.F.; Annels, N.E.; Stocken, D.D.; Pandha, H.A.; Middleton, G.W. Elevated myeloid-derived suppressor cells in pancreatic, esophageal and gastric cancer are an independent prognostic factor and are associated with significant elevation of the Th2 cytokine interleukin-13. Cancer Immunol. Immunother. 2011, 60, 1419-1430. [CrossRef] [PubMed]

42. Essner, R.; Huynh, Y.; Nguyen, T.; Rose, M.; Kojima, M.; Hoon, D.S. Functional interleukin-4 receptor and interleukin-2 receptor common gamma chain in human gastric carcinoma: A possible mechanism for cytokine-based therapy. J. Gastrointest. Surg. 2001, 5, 81-90. [CrossRef]

43. Morisaki, T.; Uchiyama, A.; Yuzuki, D.; Essner, R.; Morton, D.L.; Hoon, D.S. Interleukin 4 regulates G1 cell cycle progression in gastric carcinoma cells. Cancer Res. 1994, 54, 1113-1118. [PubMed]

44. Morisaki, T.; Yuzuki, D.H.; Lin, R.T.; Foshag, L.J.; Morton, D.L.; Hoon, D.S. Interleukin 4 receptor expression and growth inhibition of gastric carcinoma cells by interleukin 4. Cancer Res. 1992, 52, 6059-6065. [PubMed]

45. Cardenas, D.M.; Sanchez, A.C.; Rosas, D.A.; Rivero, E.; Paparoni, M.D.; Cruz, M.A.; Suarez, Y.P.; Galvis, N.F. Preliminary analysis of single-nucleotide polymorphisms in IL-10, IL-4, and IL-4Ralpha genes and profile of circulating cytokines in patients with gastric Cancer. BMC Gastroenterol. 2018, 18, 184. [CrossRef]

46. Diaz Orea, M.A.; Munoz Perez, V.; Gomez Conde, E.; Castellanos Sanchez, V.O.; Gonzalez Lopez, R.; Flores Alonso, J.C.; Cardenas, M.E.; Galicia, A.L.; Mendoza, A. Expression of Cytokines Interleukin-2, Interleukin-4, Interleukin-10 and Transforming Growth Factor beta in Gastric Adenocarcinoma Biopsies Obtained from Mexican Patients. Asian Pac. J. Cancer Prev. $2017,18,577-582$.

47. Formentini, A.; Braun, P.; Fricke, H.; Link, K.H.; Henne-Bruns, D.; Kornmann, M. Expression of interleukin-4 and interleukin-13 and their receptors in colorectal cancer. Int. J. Colorectal Dis. 2012, 27, 1369-1376. [CrossRef]

48. Iwashita, J.; Sato, Y.; Sugaya, H.; Takahashi, N.; Sasaki, H.; Abe, T. mRNA of MUC2 is stimulated by IL-4, IL-13 or TNF-alpha through a mitogen-activated protein kinase pathway in human colon cancer cells. Immunol. Cell Biol. 2003, 81, 275-282. [CrossRef]

49. Petiot, A.; Ogier-Denis, E.; Blommaart, E.F.; Meijer, A.J.; Codogno, P. Distinct classes of phosphatidylinositol 3'-kinases are involved in signaling pathways that control macroautophagy in HT-29 cells. J. Biol. Chem. 2000, 275, 992-998. [CrossRef]

50. Arico, S.; Petiot, A.; Bauvy, C.; Dubbelhuis, P.F.; Meijer, A.J.; Codogno, P.; Ogier-Denis, E. The tumor suppressor PTEN positively regulates macroautophagy by inhibiting the phosphatidylinositol 3-kinase/protein kinase B pathway. J. Biol. Chem. 2001, 276, 35243-35246. [CrossRef] 
51. Murata, T.; Noguchi, P.D.; Puri, R.K. IL-13 induces phosphorylation and activation of JAK2 Janus kinase in human colon carcinoma cell lines: Similarities between IL-4 and IL-13 signaling. J. Immunol. 1996, 156, 2972-2978. [PubMed]

52. Trejdosiewicz, L.K.; Morton, R.; Yang, Y.; Banks, R.E.; Selby, P.J.; Southgate, J. Interleukins 4 and 13 upregulate expression of cd44 in human colonic epithelial cell lines. Cytokine 1998, 10, 756-765. [CrossRef] [PubMed]

53. Morikawa, K.; Walker, S.M.; Jessup, J.M.; Fidler, I.J. In vivo selection of highly metastatic cells from surgical specimens of different primary human colon carcinomas implanted into nude mice. Cancer Res. 1988, 48, 1943-1948.

54. Xu, K.; Tao, W.; Su, Z. Propofol prevents IL-13-induced epithelial-mesenchymal transition in human colorectal cancer cells. Cell Biol. Int. 2018, 42, 985-993. [CrossRef] [PubMed]

55. Cao, H.; Zhang, J.; Liu, H.; Wan, L.; Zhang, H.; Huang, Q.; Xu, E.; Lai, M. IL-13/STAT6 signaling plays a critical role in the epithelial-mesenchymal transition of colorectal cancer cells. Oncotarget 2016, 7, 61183-61198. [CrossRef]

56. Jiang, L.; Cheng, Q.; Zhang, B.; Zhang, M. IL-13 induces the expression of 11betaHSD2 in IL-13Ralpha2 dependent manner and promotes the malignancy of colorectal cancer. Am. J. Transl. Res. 2016, 8, 1064-1072.

57. Bartolome, R.A.; Martin-Regalado, A.; Jaen, M.; Zannikou, M.; Zhang, P.; de Los Rios, V.; Balyasnikova, I.V.; Casal, J.I. Protein Tyrosine Phosphatase-1B Inhibition Disrupts IL13Ralpha2-Promoted Invasion and Metastasis in Cancer Cells. Cancers 2020, 12, 500. [CrossRef]

58. Cheadle, E.J.; Riyad, K.; Subar, D.; Rothwell, D.G.; Ashton, G.; Batha, H.; Sherlock, D.J.; Hawkins, R.E.; Gilham, D.E. Eotaxin-2 and colorectal cancer: A potential target for immune therapy. Clin. Cancer Res. 2007, 13, 5719-5728. [CrossRef]

59. Matsui, S.; Okabayashi, K.; Tsuruta, M.; Shigeta, K.; Seishima, R.; Ishida, T.; Kondo, T.; Suzuki, Y.; Hasegawa, H.; Shimoda, M.; et al. Interleukin-13 and its signaling pathway is associated with obesity-related colorectal tumorigenesis. Cancer Sci. 2019, 110, 2156-2165. [CrossRef]

60. Park, J.M.; Terabe, M.; van den Broeke, L.T.; Donaldson, D.D.; Berzofsky, J.A. Unmasking immunosurveillance against a syngeneic colon cancer by elimination of CD4+ NKT regulatory cells and IL-13. Int. J. Cancer 2005, 114, 80-87. [CrossRef]

61. Bartolomé, R.A.; Jaén, M.; Casal, J.I. An IL13R $\alpha 2$ peptide exhibits therapeutic activity against metastatic colorectal cancer. Br. J. Cancer 2018, 119, 940-949. [CrossRef] [PubMed]

62. Ingram, N.; Northwood, E.L.; Perry, S.L.; Marston, G.; Snowden, H.; Taylor, J.C.; Scott, N.; Bishop, D.T.; Coletta, P.L.; Hull, M.A Reduced type II interleukin-4 receptor signalling drives initiation, but not progression, of colorectal carcinogenesis: Evidence from transgenic mouse models and human case-control epidemiological observations. Carcinogenesis 2013, 34, 2341-2349. [CrossRef] [PubMed]

63. Saigusa, S.; Tanaka, K.; Inoue, Y.; Toiyama, Y.; Okugawa, Y.; Iwata, T.; Mohri, Y.; Kusunoki, M. Low serum interleukin-13 levels correlate with poorer prognoses for colorectal cancer patients. Int. Surg. 2014, 99, 223-229. [CrossRef] [PubMed]

64. Wang, H.P.; Wang, Y.Y.; Pan, J.; Cen, R.; Cai, Y.K. Evaluation of specific fecal protein biochips for the diagnosis of colorectal cancer. World J. Gastroenterol. 2014, 20, 1332-1339. [CrossRef] [PubMed]

65. Lahm, H.; Schnyder, B.; Wyniger, J.; Borbenyi, Z.; Yilmaz, A.; Car, B.D.; Fischer, J.R.; Givel, J.C.; Ryffel, B. Growth inhibition of human colorectal-carcinoma cells by interleukin-4 and expression of functional interleukin-4 receptors. Int. J. Cancer 1994, 59, 440-447. [CrossRef]

66. Zhou, Y.; Ji, Y.; Wang, H.; Zhang, H.; Zhou, H. IL-33 Promotes the Development of Colorectal Cancer Through Inducing Tumor-Infiltrating ST2L(+) Regulatory T Cells in Mice. Technol. Cancer Res. Treat. 2018, 17, 1-11. [CrossRef] [PubMed]

67. Kaklamanis, L.; Gatter, K.C.; Mortensen, N.; Harris, A.L. Interleukin-4 receptor and epidermal growth factor receptor expression in colorectal cancer. Br. J. Cancer 1992, 66, 712-716. [CrossRef]

68. Koller, F.L.; Hwang, D.G.; Dozier, E.A.; Fingleton, B. Epithelial interleukin-4 receptor expression promotes colon tumor growth. Carcinogenesis 2010, 31, 1010-1017. [CrossRef]

69. Chang, T.L.; Peng, X.; Fu, X.Y. Interleukin-4 mediates cell growth inhibition through activation of Stat1. J. Biol. Chem. 2000, 275, 10212-10217. [CrossRef]

70. Toi, M.; Bicknell, R.; Harris, A.L. Inhibition of colon and breast carcinoma cell growth by interleukin-4. Cancer Res. 1992, 52, 275-279.

71. Topp, M.S.; Papadimitriou, C.A.; Eitelbach, F.; Koenigsmann, M.; Oelmann, E.; Koehler, B.; Oberberg, D.; Reufi, B.; Stein, H.; Thiel, E.; et al. Recombinant human interleukin 4 has antiproliferative activity on human tumor cell lines derived from epithelial and nonepithelial histologies. Cancer Res. 1995, 55, 2173-2176. [PubMed]

72. Al-Tubuly, A.A.; Spijker, R.; Pignatelli, M.; Kirkland, S.C.; Ritter, M.A. Inhibition of growth and enhancement of differentiation of colorectal carcinoma cell lines by MAb MR6 and IL-4. Int. J. Cancer 1997, 71, 605-611. [CrossRef]

73. Schnyder, B.; Lahm, H.; Pittet, M.; Schnyder-Candrian, S. Mono- or dual-phosphorylation of akt kinase is regulated by distinct receptors that involve the common insulin receptor substrate. J. Recept. Signal Transduct. Res. 2002, 22, 213-228. [CrossRef] [PubMed]

74. Chen, J.; Gong, C.; Mao, H.; Li, Z.; Fang, Z.; Chen, Q.; Lin, M.; Jiang, X.; Hu, Y.; Wang, W.; et al. E2F1/SP3/STAT6 axis is required for IL-4-induced epithelial-mesenchymal transition of colorectal cancer cells. Int. J. Oncol. 2018, 53, 567-578. [CrossRef] [PubMed]

75. Flieger, D.; Spengler, U.; Beier, I.; Sauerbruch, T.; Schmidt-Wolf, I. Combinations of the cytokines IL-12, IL-2 and IFN-alpha significantly augment whereas the cytokine IL-4 suppresses the cytokine-induced antibody-dependent cellular cytotoxicity of monoclonal antibodies 17-1A and BR55-2. Cytokine 2000, 12, 756-761. [CrossRef] [PubMed] 
76. Wersall, P.; Masucci, G.; Mellstedt, H. Interleukin-4 augments the cytotoxic capacity of lymphocytes and monocytes in antibodydependent cellular cytotoxicity. Cancer Immunol. Immunother. 1991, 33, 45-49. [CrossRef]

77. Nagler, A.; Lanier, L.L.; Phillips, J.H. The effects of IL-4 on human natural killer cells. A potent regulator of IL-2 activation and proliferation. J. Immunol. 1988, 141, 2349-2351.

78. Qi, C.F.; Nieroda, C.; De Filippi, R.; Greiner, J.W.; Correale, P.; Schlom, J.; Tsang, K.Y. Macrophage colony-stimulating factor enhancement of antibody-dependent cellular cytotoxicity against human colon carcinoma cells. Immunol. Lett. 1995, 47, 15-24. [CrossRef]

79. Flieger, D.; Spengler, U.; Beier, I.; Kleinschmidt, R.; Hoff, A.; Varvenne, M.; Sauerbruch, T.; Schmidt-Wolf, I. Enhancement of antibody dependent cellular cytotoxicity (ADCC) by combination of cytokines. Hybridoma 1999, 18, 63-68. [CrossRef]

80. Voboril, R.; Weberova-Voborilova, J. Sensitization of colorectal cancer cells to irradiation by IL-4 and IL-10 is associated with inhibition of NF-kappaB. Neoplasma 2007, 54, 495-502.

81. Flieger, D.; Hoff, A.S.; Sauerbruch, T.; Schmidt-Wolf, I.G. Influence of cytokines, monoclonal antibodies and chemotherapeutic drugs on epithelial cell adhesion molecule (EpCAM) and LewisY antigen expression. Clin. Exp. Immunol. 2001, 123, 9-14. [CrossRef] [PubMed]

82. Lahm, H.; Amstad, P.; Yilmaz, A.; Borbenyi, Z.; Wyniger, J.; Fischer, J.R.; Suardet, L.; Givel, J.C.; Odartchenko, N. Interleukin 4 down-regulates expression of c-kit and autocrine stem cell factor in human colorectal carcinoma cells. Cell Growth Differ. 1995, 6, 1111-1118. [PubMed]

83. Wigmore, S.J.; Maingay, J.P.; Fearon, K.C.; Ross, J.A. Endogenous production of IL-8 by human colorectal cancer cells and its regulation by cytokines. Int. J. Oncol. 2001, 18, 467-473. [CrossRef] [PubMed]

84. Kanai, T.; Watanabe, M.; Hayashi, A.; Nakazawa, A.; Yajima, T.; Okazawa, A.; Yamazaki, M.; Ishii, H.; Hibi, T. Regulatory effect of interleukin-4 and interleukin-13 on colon cancer cell adhesion. Br. J. Cancer 2000, 82, 1717-1723.

85. Uchiyama, A.; Essner, R.; Doi, F.; Nguyen, T.; Ramming, K.P.; Nakamura, T.; Morton, D.L.; Hoon, D.S. Interleukin 4 inhibits hepatocyte growth factor-induced invasion and migration of colon carcinomas. J. Cell BioChem. 1996, 62, 443-453. [CrossRef]

86. Murata, T.; Noguchi, P.D.; Puri, R.K. Receptors for interleukin (IL)-4 do not associate with the common gamma chain, and IL-4 induces the phosphorylation of JAK2 tyrosine kinase in human colon carcinoma cells. J. Biol. Chem. 1995, 270, 30829-30836. [CrossRef]

87. Herzberg, F.; Schoning, M.; Schirner, M.; Topp, M.; Thiel, E.; Kreuser, E.D. IL-4 and TNF-alpha induce changes in integrin expression and adhesive properties and decrease the lung-colonizing potential of HT-29 colon carcinoma cells. Clin. Exp. Metastasis 1996, 14, 165-175. [CrossRef]

88. Gharib, A.F.; Shalaby, S.M.; Raafat, N.; Fawzy, W.M.S.; Abdel Hakim, N.H. Assessment of neutralizing interleukin-4 effect on CD133 gene expression in colon cancer cell line. Cytokine 2017, 97, 66-72. [CrossRef]

89. Li, B.H.; Yang, X.Z.; Li, P.D.; Yuan, Q.; Liu, X.H.; Yuan, J.; Zhang, W.J. IL-4/Stat6 activities correlate with apoptosis and metastasis in colon cancer cells. BioChem. Biophys. Res. Commun. 2008, 369, 554-560. [CrossRef]

90. Costamagna, D.; Duelen, R.; Penna, F.; Neumann, D.; Costelli, P.; Sampaolesi, M. Interleukin-4 administration improves muscle function, adult myogenesis, and lifespan of colon carcinoma-bearing mice. J. Cachexia Sarcopenia Muscle 2020. [CrossRef]

91. Yin, X.L.; Wang, N.; Wei, X.; Xie, G.F.; Li, J.J.; Liang, H.J. Interleukin-12 inhibits the survival of human colon cancer stem cells in vitro and their tumor initiating capacity in mice. Cancer Lett. 2012, 322, 92-97. [CrossRef]

92. Kajiwara, A.; Doi, H.; Eguchi, J.; Ishii, S.; Hiraide-Sasagawa, A.; Sakaki, M.; Omori, R.; Hiroishi, K.; Imawari, M. Interleukin-4 and $\mathrm{CpG}$ oligonucleotide therapy suppresses the outgrowth of tumors by activating tumor-specific Th1-type immune responses. Oncol. Rep. 2012, 27, 1765-1771. [PubMed]

93. Liu, Y.J.; Dou, X.Q.; Wang, F.; Zhang, J.; Wang, X.L.; Xu, G.L.; Xiang, S.S.; Gao, X.; Fu, J.; Song, H.F. IL-4Ralpha aptamer-liposomeCpG oligodeoxynucleotides suppress tumour growth by targeting the tumour microenvironment. J. Drug Target. 2017, 25, 275-283. [CrossRef] [PubMed]

94. Itsuki, Y.; Suzuki, S. Expression of interleukin-4 in colon 26 cells induces both eosinophil mediated local tumor killing and T-cell mediated systemic immunity in vivo. Nihon Ika Daigaku Zasshi 1996, 63, 275-285. [CrossRef] [PubMed]

95. Eguchi, J.; Hiroishi, K.; Ishii, S.; Baba, T.; Matsumura, T.; Hiraide, A.; Okada, H.; Imawari, M. Interleukin-4 gene transduced tumor cells promote a potent tumor-specific Th1-type response in cooperation with interferon-alpha transduction. Gene Ther. 2005, 12, 733-741. [CrossRef]

96. Yamaguchi, M.; Okamura, S.; Yamaji, T.; Iwasaki, M.; Tsugane, S.; Shetty, V.; Koizumi, T. Plasma cytokine levels and the presence of colorectal cancer. PLoS ONE 2019, 14, e0213602. [CrossRef]

97. Berghella, A.M.; Pellegrini, P.; Del Beato, T.; Maccarone, D.; Adorno, D.; Casciani, C.U. Prognostic significance of immunological evaluation in colorectal cancer. Cancer BioTher. Radiopharm. 1996, 11, 355-361. [CrossRef]

98. Berghella, A.M.; Contasta, I.; Pellegrini, P.; Del Beato, T.; Adorno, D. Peripheral blood immunological parameters for use as markers of pre-invasive to invasive colorectal cancer. Cancer BioTher. Radiopharm. 2002, 17, 43-50. [CrossRef]

99. Zaloudik, J.; Lauerova, L.; Janakova, L.; Talac, R.; Simickova, M.; Nekulova, M.; Mikulikova, I.; Kovarik, J.; Sheard, M. Significance of pre-treatment immunological parameters in colorectal cancer patients with unresectable metastases to the liver. Hepatogastroenterology 1999, 46, 220-227.

100. Pellegrini, P.; Berghella, A.M.; Del Beato, T.; Maccarone, D.; Cencioni, S.; Adorno, D.; Casciani, C.U. The sCEA molecule suppressive role in NK and TH1 cell functions in colorectal cancer. Cancer BioTher. Radiopharm. 1997, 12, 257-264. [CrossRef] 
101. Kim, Y.W.; Kim, S.K.; Kim, C.S.; Kim, I.Y.; Cho, M.Y.; Kim, N.K. Association of serum and intratumoral cytokine profiles with tumor stage and neutrophil lymphocyte ratio in colorectal cancer. Anticancer Res. 2014, 34, 3481-3487.

102. Di Stefano, A.B.; Iovino, F.; Lombardo, Y.; Eterno, V.; Hoger, T.; Dieli, F.; Stassi, G.; Todaro, M. Survivin is regulated by interleukin-4 in colon cancer stem cells. J. Cell Physiol. 2010, 225, 555-561. [CrossRef] [PubMed]

103. Todaro, M.; Lombardo, Y.; Francipane, M.G.; Alea, M.P.; Cammareri, P.; Iovino, F.; Di Stefano, A.B.; Di Bernardo, C.; Agrusa, A.; Condorelli, G.; et al. Apoptosis resistance in epithelial tumors is mediated by tumor-cell-derived interleukin-4. Cell Death Differ. 2008, 15, 762-772. [CrossRef] [PubMed]

104. Kim, S.T.; Sohn, I.; Do, I.G.; Jang, J.; Kim, S.H.; Jung, I.H.; Park, J.O.; Park, Y.S.; Talasaz, A.; Lee, J.; et al. Transcriptome analysis of CD133-positive stem cells and prognostic value of survivin in colorectal cancer. Cancer Genom. Proteom. 2014, 11, 259-266. [CrossRef]

105. Volonte, A.; Di Tomaso, T.; Spinelli, M.; Todaro, M.; Sanvito, F.; Albarello, L.; Bissolati, M.; Ghirardelli, L.; Orsenigo, E.; Ferrone, S.; et al. Cancer-initiating cells from colorectal cancer patients escape from T cell-mediated immunosurveillance in vitro through membrane-bound IL-4. J. Immunol. 2014, 192, 523-532. [CrossRef] [PubMed]

106. Barth, R.J., Jr.; Camp, B.J.; Martuscello, T.A.; Dain, B.J.; Memoli, V.A. The cytokine microenvironment of human colon carcinoma. Lymphocyte expression of tumor necrosis factor-alpha and interleukin-4 predicts improved survival. Cancer 1996, 78, 1168-1178. [CrossRef]

107. Correale, P.; Botta, C.; Staropoli, N.; Nardone, V.; Pastina, P.; Ulivieri, C.; Gandolfo, C.; Baldari, T.C.; Lazzi, S.; Ciliberto, D.; et al. Systemic inflammatory status predict the outcome of k-RAS WT metastatic colorectal cancer patients receiving the thymidylate synthase poly-epitope-peptide anticancer vaccine. Oncotarget 2018, 9, 20539-20554. [CrossRef]

108. Evans, C.F.; Galustian, C.; Bodman-Smith, M.; Dalgleish, A.G.; Kumar, D. The effect of colorectal cancer upon host peripheral immune cell function. Colorectal Dis. Off. J. Assoc. Coloproctol. Great Br. Irel. 2010, 12, 561-569. [CrossRef]

109. Purasiri, P.; Murray, A.; Richardson, S.; Heys, S.D.; Horrobin, D.; Eremin, O. Modulation of cytokine production in vivo by dietary essential fatty acids in patients with colorectal cancer. Clin. Sci. 1994, 87, 711-717. [CrossRef]

110. Risch, N.J. Searching for genetic determinants in the new millennium. Nature 2000, 405, 847-856. [CrossRef]

111. Botstein, D.; Risch, N. Discovering genotypes underlying human phenotypes: Past successes for mendelian disease, future approaches for complex disease. Nat. Genet. 2003, 33, 228-237. [CrossRef] [PubMed]

112. Cascorbi, I.; Henning, S.; Brockmoller, J.; Gephart, J.; Meisel, C.; Muller, J.M.; Loddenkemper, R.; Roots, I. Substantially reduced risk of cancer of the aerodigestive tract in subjects with variant-463A of the myeloperoxidase gene. Cancer Res. 2000, 60, 644-649. [PubMed]

113. Piedrafita, F.J.; Molander, R.B.; Vansant, G.; Orlova, E.A.; Pfahl, M.; Reynolds, W.F. An Alu element in the myeloperoxidase promoter contains a composite SP1-thyroid hormone-retinoic acid response element. J. Biol. Chem. 1996, 271, 14412-14420. [CrossRef] [PubMed]

114. Chin, L.J.; Ratner, E.; Leng, S.; Zhai, R.; Nallur, S.; Babar, I.; Muller, R.U.; Straka, E.; Su, L.; Burki, E.A.; et al. A SNP in a let-7 microRNA complementary site in the KRAS 3' untranslated region increases non-small cell lung cancer risk. Cancer Res. 2008, 68, 8535-8540. [CrossRef]

115. Erichsen, H.C.; Chanock, S.J. SNPs in cancer research and treatment. Br. J. Cancer 2004, 90, 747-751. [CrossRef] [PubMed]

116. El-Omar, E.M.; Rabkin, C.S.; Gammon, M.D.; Vaughan, T.L.; Risch, H.A.; Schoenberg, J.B.; Stanford, J.L.; Mayne, S.T.; Goedert, J.; Blot, W.J.; et al. Increased risk of noncardia gastric cancer associated with proinflammatory cytokine gene polymorphisms. Gastroenterology 2003, 124, 1193-1201. [CrossRef]

117. Wu, M.S.; Wu, C.Y.; Chen, C.J.; Lin, M.T.; Shun, C.T.; Lin, J.T. Interleukin-10 genotypes associate with the risk of gastric carcinoma in Taiwanese Chinese. Int. J. Cancer 2003, 104, 617-623. [CrossRef]

118. Lai, K.C.; Chen, W.C.; Jeng, L.B.; Li, S.Y.; Chou, M.C.; Tsai, F.J. Association of genetic polymorphisms of MK, IL-4, p16, p21, p53 genes and human gastric cancer in Taiwan. Eur. J. Surg. Oncol. 2005, 31, 1135-1140. [CrossRef]

119. Garcia-Gonzalez, M.A.; Lanas, A.; Quintero, E.; Nicolas, D.; Parra-Blanco, A.; Strunk, M.; Benito, R.; Angel Simon, M.; Santolaria, S.; Sopena, F.; et al. Gastric cancer susceptibility is not linked to pro-and anti-inflammatory cytokine gene polymorphisms in whites: A Nationwide Multicenter Study in Spain. Am. J. Gastroenterol. 2007, 102, 1878-1892. [CrossRef]

120. Crusius, J.B.; Canzian, F.; Capella, G.; Pena, A.S.; Pera, G.; Sala, N.; Agudo, A.; Rico, F.; Del Giudice, G.; Palli, D.; et al. Cytokine gene polymorphisms and the risk of adenocarcinoma of the stomach in the European prospective investigation into cancer and nutrition (EPIC-EURGAST). Ann. Oncol. 2008, 19, 1894-1902. [CrossRef]

121. Zambon, C.F.; Basso, D.; Marchet, A.; Fasolo, M.; Stranges, A.; Schiavon, S.; Navaglia, F.; Greco, E.; Fogar, P.; Falda, A.; et al. IL-4 $-588 \mathrm{C}>\mathrm{T}$ polymorphism and IL-4 receptor alpha [Ex5+14A>G.; Ex11+828A $>$ G] haplotype concur in selecting H. pylori cagA subtype infections. Clin. Chim. Acta 2008, 389, 139-145. [CrossRef] [PubMed]

122. Ando, T.; Ishikawa, T.; Kato, H.; Yoshida, N.; Naito, Y.; Kokura, S.; Yagi, N.; Takagi, T.; Handa, O.; Kitawaki, J.; et al. Synergistic effect of HLA class II loci and cytokine gene polymorphisms on the risk of gastric cancer in Japanese patients with Helicobacter pylori infection. Int. J. Cancer 2009, 125, 2595-2602. [CrossRef] [PubMed]

123. Ko, K.P.; Park, S.K.; Cho, L.Y.; Gwack, J.; Yang, J.J.; Shin, A.; Kim, C.S.; Kim, Y.; Kang, D.; Chang, S.H.; et al. Soybean product intake modifies the association between interleukin-10 genetic polymorphisms and gastric cancer risk. J. Nutr. 2009, 139, 1008-1012. [CrossRef] [PubMed] 
124. Wu, J.; Lu, Y.; Ding, Y.B.; Ke, Q.; Hu, Z.B.; Yan, Z.G.; Xue, Y.; Zhou, Y.; Hua, Z.L.; Shu, Y.Q.; et al. Promoter polymorphisms of IL2, IL4, and risk of gastric cancer in a high-risk Chinese population. Mol. Carcinog. 2009, 48, 626-632. [CrossRef] [PubMed]

125. Pan, X.F.; Wen, Y.; Loh, M.; Wen, Y.Y.; Yang, S.J.; Zhao, Z.M.; Tian, Z.; Huang, H.; Lan, H.; Chen, F.; et al. Interleukin-4 and -8 gene polymorphisms and risk of gastric cancer in a population in Southwestern China. Asian Pac. J. Cancer Prev. 2014, 15, $2951-2957$. [CrossRef]

126. Yin, J.; Wang, X.; Wei, J.; Wang, L.; Shi, Y.; Zheng, L.; Tang, W.; Ding, G.; Liu, C.; Liu, R.; et al. Interleukin $12 B$ rs3212227 T > G polymorphism was associated with an increased risk of gastric cardiac adenocarcinoma in a Chinese population. Dis. Esophagus 2015, 28, 291-298. [CrossRef]

127. Martinez-Campos, C.; Torres-Poveda, K.; Camorlinga-Ponce, M.; Flores-Luna, L.; Maldonado-Bernal, C.; Madrid-Marina, V.; Torres, J. Polymorphisms in IL-10 and TGF-beta gene promoter are associated with lower risk to gastric cancer in a Mexican population. BMC Cancer 2019, 19, 453. [CrossRef]

128. He, B.; Pan, B.; Pan, Y.; Sun, H.; Xu, T.; Qin, J.; Xu, X.; Wang, S. IL-4/IL-4R and IL-6/IL-6R genetic variations and gastric cancer risk in the Chinese population. Am. J. Transl. Res. 2019, 11, 3698-3706.

129. Yun, Y.; Dong, W.; Chen, C.; Zhang, H.; Shi, N.; He, M.; Chen, X. Roles of IL-4 genetic polymorphisms and haplotypes in the risk of gastric cancer and their interaction with environmental factors. Int. J. Clin. Exp. Pathol. 2017, 10, 8936-8943.

130. Burada, F.; Angelescu, C.; Mitrut, P.; Ciurea, T.; Cruce, M.; Saftoiu, A.; Ioana, M. Interleukin-4 receptor $-3223 T \rightarrow$ C polymorphism is associated with increased gastric adenocarcinoma risk. Can. J. Gastroenterol. 2012, 26, 532-536. [CrossRef]

131. Xia, H.Z.; Du, W.D.; Wu, Q.; Chen, G.; Zhou, Y.; Tang, X.F.; Tang, H.Y.; Liu, Y.; Yang, F.; Ruan, J.; et al. E-selectin rs5361 and FCGR2A rs1801274 variants were associated with increased risk of gastric cancer in a Chinese population. Mol. Carcinog. 2012, 51,597-607. [CrossRef] [PubMed]

132. Bhayal, A.C.; Krishnaveni, D.; Rao, K.P.; Kumar, A.R.; Jyothy, A.; Nallari, P.; Venkateshwari, A. Significant Association of Interleukin4 Intron 3 VNTR Polymorphism with Susceptibility to Gastric Cancer in a South Indian Population from Telangana. PLoS ONE 2015, 10, e0138442. [CrossRef] [PubMed]

133. Sampaio, A.M.; Balseiro, S.C.; Silva, M.R.; Alarcao, A.; d'Aguiar, M.J.; Ferreira, T.; Carvalho, L. Association Between IL-4 and IL-6 Expression Variants and Gastric Cancer Among Portuguese Population. GE Port. J. Gastroenterol. 2015, 22, 143-152. [CrossRef] [PubMed]

134. Seno, H.; Satoh, K.; Tsuji, S.; Shiratsuchi, T.; Harada, Y.; Hamajima, N.; Sugano, K.; Kawano, S.; Chiba, T. Novel interleukin-4 and interleukin-1 receptor antagonist gene variations associated with non-cardia gastric cancer in Japan: Comprehensive analysis of 207 polymorphisms of 11 cytokine genes. J. Gastroenterol. Hepatol. 2007, 22, 729-737. [CrossRef]

135. Wang, Y.; Li, H.; Wang, X.; Gao, F.; Yu, L.; Chen, X. Association between four SNPs in IL-4 and the risk of gastric cancer in a Chinese population. Int. J. Mol. Epidemiol. Genet. 2017, 8, 45-52.

136. Pavithra, D.; Gautam, M.; Rama, R.; Swaminathan, R.; Gopal, G.; Ramakrishnan, A.S.; Rajkumar, T. TGFbeta C-509T, TGFbeta T869C, XRCC1 Arg194Trp, IKBalpha C642T, IL4 C-590T Genetic polymorphisms combined with socio-economic, lifestyle, diet factors and gastric cancer risk: A case control study in South Indian population. Cancer Epidemiol. 2018, 53, 21-26. [CrossRef]

137. Cavalcante, G.C.; Amador, M.A.; Ribeiro Dos Santos, A.M.; Carvalho, D.C.; Andrade, R.B.; Pereira, E.E.; Fernandes, M.R.; Costa, D.F.; Santos, N.P.; Assumpcao, P.P.; et al. Analysis of 12 variants in the development of gastric and colorectal cancers. World J. Gastroenterol. 2017, 23, 8533-8543. [CrossRef]

138. Yang, S.; Park, Y.; Lee, J.; Choi, I.J.; Kim, Y.W.; Ryu, K.W.; Sung, J.; Kim, J. Effects of Soy Product Intake and Interleukin Genetic Polymorphisms on Early Gastric Cancer Risk in Korea: A Case-Control Study. Cancer Res. Treat. 2017, 49, 1044-1056. [CrossRef]

139. Wang, Y.M.; Li, Z.X.; Tang, F.B.; Zhang, Y.; Zhou, T.; Zhang, L.; Ma, J.L.; You, W.C.; Pan, K.F. Association of genetic polymorphisms of interleukins with gastric cancer and precancerous gastric lesions in a high-risk Chinese population. Tumour Biol. 2016, 37, 2233-2242. [CrossRef]

140. Schmidt, H.M.; Ha, D.M.; Taylor, E.F.; Kovach, Z.; Goh, K.L.; Fock, K.M.; Barrett, J.H.; Forman, D.; Mitchell, H. Variation in human genetic polymorphisms, their association with Helicobacter pylori acquisition and gastric cancer in a multi-ethnic country. J. Gastroenterol. Hepatol. 2011, 26, 1725-1732. [CrossRef]

141. Garcia-Gonzalez, M.A.; Nicolas-Perez, D.; Lanas, A.; Bujanda, L.; Carrera, P.; Benito, R.; Strunk, M.; Sopena, F.; Santolaria, S.; Piazuelo, E.; et al. Prognostic role of host cyclooxygenase and cytokine genotypes in a Caucasian cohort of patients with gastric adenocarcinoma. PLoS ONE 2012, 7, e46179. [CrossRef] [PubMed]

142. Talebkhan, Y.; Doozbakhshan, M.; Saberi, S.; Esmaeili, M.; Karami, N.; Mohajerani, N.; Abdirad, A.; Eshagh Hosseini, M.; Nahvijou, A.; Mohagheghi, M.A.; et al. Serum Antibodies against Helicobacter pylori Neutrophil Activating Protein in Carriers of IL-4 C-590T Genetic Polymorphism Amplify the Risk of Gastritis and Gastric Cancer. Iran. Biomed. J. 2017, 21, 321-329. [CrossRef] [PubMed]

143. Walczak, A.; Przybylowska, K.; Trzcinski, R.; Sygut, A.; Dziki, L.; Dziki, A.; Majsterek, I. Association of -1112 c/t promoter region polymorphism of the interleukin 13 gene with occurrence of colorectal cancer. Pol. J. Surg. 2011, 83, 27-31. [CrossRef]

144. Ibrahimi, M.; Moossavi, M.; Mojarad, E.N.; Musavi, M.; Mohammadoo-Khorasani, M.; Shahsavari, Z. Positive correlation between interleukin-1 receptor antagonist gene 86bp VNTR polymorphism and colorectal cancer susceptibility: A case-control study. Immunol. Res. 2019, 67, 151-156. [CrossRef] [PubMed]

145. Landi, S.; Bottari, F.; Gemignani, F.; Gioia-Patricola, L.; Guino, E.; Osorio, A.; de Oca, J.; Capella, G.; Canzian, F.; Moreno, V.; et al. Interleukin-4 and interleukin-4 receptor polymorphisms and colorectal cancer risk. Eur. J. Cancer 2007, 43, 762-768. [CrossRef] 
146. Lee, Y.S.; Choi, H.B.; Lee, I.K.; Kim, T.G.; Oh, S.T. Association between interleukin-4R and TGF-beta1 gene polymorphisms and the risk of colorectal cancer in a Korean population. Colorectal Dis. Off. J. Assoc. Coloproctol. Great Br. Irel. 2010, 12, 1208-1212.

147. Cozar, J.M.; Romero, J.M.; Aptsiauri, N.; Vazquez, F.; Vilchez, J.R.; Tallada, M.; Garrido, F.; Ruiz-Cabello, F. High incidence of CTLA-4 AA (CT60) polymorphism in renal cell cancer. Hum. Immunol. 2007, 68, 698-704. [CrossRef]

148. Suchy, J.; Klujszo-Grabowska, E.; Kladny, J.; Cybulski, C.; Wokolorczyk, D.; Szymanska-Pasternak, J.; Kurzawski, G.; Scott, R.J.; Lubinski, J. Inflammatory response gene polymorphisms and their relationship with colorectal cancer risk. BMC Cancer 2008, 8, 112. [CrossRef]

149. Wilkening, S.; Tavelin, B.; Canzian, F.; Enquist, K.; Palmqvist, R.; Altieri, A.; Hallmans, G.; Hemminki, K.; Lenner, P.; Forsti, A. Interleukin promoter polymorphisms and prognosis in colorectal cancer. Carcinogenesis 2008, 29, 1202-1206. [CrossRef]

150. Shamoun, L.; Skarstedt, M.; Andersson, R.E.; Wagsater, D.; Dimberg, J. Association study on IL-4, IL-4Ralpha and IL-13 genetic polymorphisms in Swedish patients with colorectal cancer. Clin. Chim. Acta 2018, 487, 101-106. [CrossRef]

151. Yu, Y.; Zhou, J.; Gong, C.; Long, Z.; Tian, J.; Zhu, L.; Li, J.; Yu, H.; Wang, F.; Zhao, Y. Dietary factors and microRNA-binding site polymorphisms in the IL13 gene: Risk and prognosis analysis of colorectal cancer. Oncotarget 2017, 8, 47379-47388. [CrossRef] [PubMed]

152. Yu, Y.; Zheng, S.; Zhang, S.; Jin, W.; Liu, H.; Jin, M.; Chen, Z.; Ding, Z.; Wang, L.; Chen, K. Polymorphisms of inflammation-related genes and colorectal cancer risk: A population-based case-control study in China. Int. J. Immunogenet. 2014, 41, $289-297$. [CrossRef] [PubMed]

153. Marques, D.; Ferreira-Costa, L.R.; Ferreira-Costa, L.L.; Correa, R.D.S.; Borges, A.M.P.; Ito, F.R.; Ramos, C.C.O.; Bortolin, R.H.; Luchessi, A.D.; Ribeiro-Dos-Santos, A.; et al. Association of insertion-deletions polymorphisms with colorectal cancer risk and clinical features. World J. Gastroenterol. 2017, 23, 6854-6867. [CrossRef] [PubMed]

154. Walczak, A.; Przybylowska, K.; Dziki, L.; Sygut, A.; Chojnacki, C.; Chojnacki, J.; Dziki, A.; Majsterek, I. The lL-8 and IL-13 gene polymorphisms in inflammatory bowel disease and colorectal cancer. DNA Cell Biol. 2012, 31, 1431-1438. [CrossRef]

155. Zamora-Ros, R.; Shivappa, N.; Steck, S.E.; Canzian, F.; Landi, S.; Alonso, M.H.; Hebert, J.R.; Moreno, V. Dietary inflammatory index and inflammatory gene interactions in relation to colorectal cancer risk in the Bellvitge colorectal cancer case-control study. Genes Nutr. 2015, 10, 447. [CrossRef]

156. Wen, X.; Xin, X.; Li, J.; Qiao, L.; Liu, F.; Guo, Y.; Qu, Z.; Wang, R.; Li, X. The correlation between IL-4 polymorphisms and colorectal cancer risk in a population in Northwest China. Eur. J. Cancer Prev. 2020, 29, 95-99. [CrossRef]

157. Burada, F.; Dumitrescu, T.; Nicoli, R.; Ciurea, M.E.; Rogoveanu, I.; Ioana, M. Cytokine promoter polymorphisms and risk of colorectal cancer. Clin. Lab. 2013, 59, 773-779. [CrossRef]

158. Yannopoulos, A.; Nikiteas, N.; Chatzitheofylaktou, A.; Tsigris, C. The (-590 C/T) polymorphism in the interleukin-4 gene is associated with increased risk for early stages of corolectal adenocarcinoma. In Vivo 2007, 21, 1031-1035.

159. Talseth, B.A.; Meldrum, C.; Suchy, J.; Kurzawski, G.; Lubinski, J.; Scott, R.J. Lack of association between genetic polymorphisms in cytokine genes and disease expression in patients with hereditary non-polyposis colorectal cancer. Scand J. Gastroenterol. 2007, 42, 628-632. [CrossRef]

160. Sainz, J.; Rudolph, A.; Hoffmeister, M.; Frank, B.; Brenner, H.; Chang-Claude, J.; Hemminki, K.; Forsti, A. Effect of type 2 diabetes predisposing genetic variants on colorectal cancer risk. J. Clin. Endocrinol. Metab. 2012, 97, E845-E851. [CrossRef]

161. Xiao, L.; Yu, X.; Zhang, R.; Chang, H.; Xi, S.; Xiao, W.; Zeng, Z.; Zhang, H.; Xu, R.; Gao, Y. Can an IL13 -1112 C/T (rs1800925) polymorphism predict responsiveness to neoadjuvant chemoradiotherapy and survival of Chinese Han patients with locally advanced rectal cancer? Oncotarget 2016, 7, 34149-34157. [CrossRef] [PubMed]

162. Ho-Pun-Cheung, A.; Assenat, E.; Bascoul-Mollevi, C.; Bibeau, F.; Boissiere-Michot, F.; Thezenas, S.; Cellier, D.; Azria, D.; Rouanet, P.; Senesse, P.; et al. A large-scale candidate gene approach identifies SNPs in SOD2 and IL13 as predictive markers of response to preoperative chemoradiation in rectal cancer. Pharm. J. 2011, 11, 437-443. [CrossRef] [PubMed]

163. Xie, Z.; Wang, B.; Chai, Y.; Chen, J. Estimation of associations between 10 common gene polymorphisms and gastric cancer: Evidence from a meta-analysis. J. Clin. Pathol. 2020, 73, 318-321. [CrossRef] [PubMed]

164. Zhang, J.; Xie, D.; Zhou, H.; Fan, R.; Zhang, L.; Li, C.; Jin, S.; Meng, Q.; Lu, J. The -590C/T polymorphism in the IL-4 gene and the risk of cancer: A meta-analysis. Tumour Biol. 2013, 34, 2261-2268. [CrossRef]

165. Cho, Y.A.; Kim, J. Association of IL4, IL13, and IL4R polymorphisms with gastrointestinal cancer risk: A meta-analysis. J. Epidemiol. 2017, 27, 215-220. [CrossRef]

166. Sun, Z.; Cui, Y.; Jin, X.; Pei, J. Association between IL-4 -590C >T polymorphism and gastric cancer risk. Tumour Biol. 2014, 35, 1517-1521. [CrossRef]

167. Wang, T.; Tian, L.; Gao, M.; Song, H.; Wei, Y.; Xue, Y. Interleukin (IL)-4 -590C>T polymorphism is not associated with the susceptibility of gastric cancer: An updated meta-analysis. Ann. Med. Surg. 2016, 9, 1-5. [CrossRef]

168. Zhang, C.; Huang, J.Y.; He, Z.Q.; Weng, H. Genetic association between interluekin-4 rs2243250 polymorphism and gastric cancer susceptibility: Evidence based on a meta-analysis. Onco Targets Ther. 2016, 9, 2403-2408. [CrossRef]

169. Jia, Y.; Xie, X.; Shi, X.; Li, S. Associations of common IL-4 gene polymorphisms with cancer risk: A meta-analysis. Mol. Med. Rep. 2017, 16, 1927-1945. [CrossRef]

170. Liu, Y.; Xu, Y.; Wang, Y.; Yao, Y.; Yang, J. Associations between interleukin gene polymorphisms and the risk of gastric cancer: A meta-analysis. Clin. Exp. Pharmacol. Physiol. 2018, 45, 1236-1244. [CrossRef] 
171. Loh, M.; Koh, K.X.; Yeo, B.H.; Song, C.M.; Chia, K.S.; Zhu, F.; Yeoh, K.G.; Hill, J.; Iacopetta, B.; Soong, R. Meta-analysis of genetic polymorphisms and gastric cancer risk: Variability in associations according to race. Eur. J. Cancer 2009, 45, 2562-2568. [CrossRef] [PubMed]

172. Sugimoto, M.; Yamaoka, Y.; Furuta, T. Influence of interleukin polymorphisms on development of gastric cancer and peptic ulcer. World J. Gastroenterol. 2010, 16, 1188-1200. [CrossRef] [PubMed]

173. Wu, H.; Hu, J.; Liu, B.; Tao, Y.; Zhou, X.; Yuan, X. Lack of association between interleukin-4 -524C $>$ T polymorphism and colorectal cancer susceptibility. Tumour Biol. 2014, 35, 3657-3662. [CrossRef] [PubMed]

174. Li, Q.; Wang, Q.; Xu, X.; Ren, S.; Wang, L. Association between IL-4 -589C>T polymorphism and colorectal cancer risk. Tumour Biol. 2014, 35, 2675-2679. [CrossRef] [PubMed]

175. Hallett, M.A.; Venmar, K.T.; Fingleton, B. Cytokine stimulation of epithelial cancer cells: The similar and divergent functions of IL-4 and IL-13. Cancer Res. 2012, 72, 6338-6343. [CrossRef]

176. Prokopchuk, O.; Liu, Y.; Henne-Bruns, D.; Kornmann, M. Interleukin-4 enhances proliferation of human pancreatic cancer cells: Evidence for autocrine and paracrine actions. Br. J. Cancer 2005, 92, 921-928. [CrossRef]

177. Ito, S.E.; Shirota, H.; Kasahara, Y.; Saijo, K.; Ishioka, C. IL-4 blockade alters the tumor microenvironment and augments the response to cancer immunotherapy in a mouse model. Cancer Immunol. Immunother. 2017, 66, 1485-1496. [CrossRef]

178. Rubin, J.T.; Lotze, M.T. Acute gastric mucosal injury associated with the systemic administration of interleukin-4. Surgery 1992, $111,274-280$.

179. Braddock, M.; Hanania, N.A.; Sharafkhaneh, A.; Colice, G.; Carlsson, M. Potential Risks Related to Modulating Interleukin-13 and Interleukin-4 Signalling: A Systematic Review. Drug Saf. 2018, 41, 489-509. [CrossRef]

180. Debinski, W.; Puri, R.K.; Kreitman, R.J.; Pastan, I. A wide range of human cancers express interleukin 4 (IL4) receptors that can be targeted with chimeric toxin composed of IL4 and Pseudomonas exotoxin. J. Biol. Chem. 1993, 268, 14065-14070. [CrossRef]

181. Shimamura, T.; Royal, R.E.; Kioi, M.; Nakajima, A.; Husain, S.R.; Puri, R.K. Interleukin-4 cytotoxin therapy synergizes with gemcitabine in a mouse model of pancreatic ductal adenocarcinoma. Cancer Res. 2007, 67, 9903-9912. [CrossRef]

182. Ishige, K.; Shoda, J.; Kawamoto, T.; Matsuda, S.; Ueda, T.; Hyodo, I.; Ohkohchi, N.; Puri, R.K.; Kawakami, K. Potent in vitro and in vivo antitumor activity of interleukin-4-conjugated Pseudomonas exotoxin against human biliary tract carcinoma. Int. J. Cancer 2008, 123, 2915-2922. [CrossRef]

183. Debinski, W.; Obiri, N.I.; Powers, S.K.; Pastan, I.; Puri, R.K. Human glioma cells overexpress receptors for interleukin 13 and are extremely sensitive to a novel chimeric protein composed of interleukin 13 and pseudomonas exotoxin. Clin. Cancer Res. 1995, 1, 1253-1258. [PubMed]

184. NCT00014677. Available online: https://clinicaltrials.gov/ct2/show/NCT00014677 (accessed on 1 August 2020).

185. Kunwar, S.; Chang, S.; Westphal, M.; Vogelbaum, M.; Sampson, J.; Barnett, G.; Shaffrey, M.; Ram, Z.; Piepmeier, J.; Prados, M.; et al. Phase III randomized trial of CED of IL13-PE38QQR vs Gliadel wafers for recurrent glioblastoma. Neuro-Oncology 2010, 12, 871-881. [CrossRef] [PubMed]

186. Yang, L.; Horibe, T.; Kohno, M.; Haramoto, M.; Ohara, K.; Puri, R.K.; Kawakami, K. Targeting interleukin-4 receptor alpha with hybrid peptide for effective cancer therapy. Mol. Cancer Ther. 2012, 11, 235-243. [CrossRef] [PubMed]

187. Yang, F.Y.; Wong, T.T.; Teng, M.C.; Liu, R.S.; Lu, M.; Liang, H.F.; Wei, M.C. Focused ultrasound and interleukin-4 receptor-targeted liposomal doxorubicin for enhanced targeted drug delivery and antitumor effect in glioblastoma multiforme. J. Control. Release 2012, 160, 652-658. [CrossRef] [PubMed]

188. Ulasov, I.V.; Tyler, M.A.; Han, Y.; Glasgow, J.N.; Lesniak, M.S. Novel recombinant adenoviral vector that targets the interleukin-13 receptor alpha2 chain permits effective gene transfer to malignant glioma. Hum. Gene Ther. 2007, 18, 118-129. [CrossRef] [PubMed]

189. Balyasnikova, I.V.; Wainwright, D.A.; Solomaha, E.; Lee, G.; Han, Y.; Thaci, B.; Lesniak, M.S. Characterization and immunotherapeutic implications for a novel antibody targeting interleukin (IL)-13 receptor alpha2. J. Biol. Chem. 2012, 287, 30215-30227. [CrossRef]

190. Pollack, I.F.; Jakacki, R.I.; Butterfield, L.H.; Hamilton, R.L.; Panigrahy, A.; Potter, D.M.; Connelly, A.K.; Dibridge, S.A.; Whiteside, T.L.; Okada, H. Antigen-specific immune responses and clinical outcome after vaccination with glioma-associated antigen peptides and polyinosinic-polycytidylic acid stabilized by lysine and carboxymethylcellulose in children with newly diagnosed malignant brainstem and nonbrainstem gliomas. J. Clin. Oncol. 2014, 32, 2050-2058.

191. Pollack, I.F.; Jakacki, R.I.; Butterfield, L.H.; Hamilton, R.L.; Panigrahy, A.; Normolle, D.P.; Connelly, A.K.; Dibridge, S.; Mason, G.; Whiteside, T.L.; et al. Immune responses and outcome after vaccination with glioma-associated antigen peptides and poly-ICLC in a pilot study for pediatric recurrent low-grade gliomas. Neuro-Oncology 2016, 18, 1157-1168. [CrossRef]

192. NCT01280552. Available online: http:/ / clinicaltrials.gov/show/NCT01280552 (accessed on 1 August 2020).

193. Kong, S.; Sengupta, S.; Tyler, B.; Bais, A.J.; Ma, Q.; Doucette, S.; Zhou, J.; Sahin, A.; Carter, B.S.; Brem, H.; et al. Suppression of human glioma xenografts with second-generation IL13R-specific chimeric antigen receptor-modified T cells. Clin. Cancer Res. 2012, 18, 5949-5960. [CrossRef] [PubMed]

194. Terabe, M.; Matsui, S.; Noben-Trauth, N.; Chen, H.; Watson, C.; Donaldson, D.D.; Carbone, D.P.; Paul, W.E.; Berzofsky, J.A. NKT cell-mediated repression of tumor immunosurveillance by IL-13 and the IL-4R-STAT6 pathway. Nat. Immunol. 2000, 1, 515-520. [CrossRef] [PubMed] 
195. Hanahan, D.; Coussens, L.M. Accessories to the crime: Functions of cells recruited to the tumor microenvironment. Cancer Cell 2012, 21, 309-322. [CrossRef]

196. Pitt, J.M.; Marabelle, A.; Eggermont, A.; Soria, J.C.; Kroemer, G.; Zitvogel, L. Targeting the tumor microenvironment: Removing obstruction to anticancer immune responses and immunotherapy. Ann. Oncol. 2016, 27, 1482-1492. [CrossRef]

197. Noy, R.; Pollard, J.W. Tumor-associated macrophages: From mechanisms to therapy. Immunity 2014, 41, 49-61. [CrossRef] [PubMed]

198. Coussens, L.M.; Zitvogel, L.; Palucka, A.K. Neutralizing tumor-promoting chronic inflammation: A magic bullet? Science 2013, 339, 286-291. [CrossRef] [PubMed]

199. Santoni, M.; Massari, F.; Amantini, C.; Nabissi, M.; Maines, F.; Burattini, L.; Berardi, R.; Santoni, G.; Montironi, R.; Tortora, G.; et al. Emerging role of tumor-associated macrophages as therapeutic targets in patients with metastatic renal cell carcinoma. Cancer Immunol. Immunother. 2013, 62, 1757-1768. [CrossRef]

200. Zhao, G.; Liu, L.; Peek, R.M., Jr.; Hao, X.; Polk, D.B.; Li, H.; Yan, F. Activation of Epidermal Growth Factor Receptor in Macrophages Mediates Feedback Inhibition of M2 Polarization and Gastrointestinal Tumor Cell Growth. J. Biol. Chem. 2016, 291, 20462-20472. [CrossRef] 